\title{
Synthesis, Absorption and Fluorescence Spectral Characteristics of Trinucleus Dimethine Cyanine Dyes as Fluorescent Probes for DNA Detection
}

\author{
Jun-Jie Su, ${ }^{a}$ Lan-Ying Wang, ${ }^{*, a}$ Xiang-Han Zhang, ${ }^{a}$ Yi-Le Fu, ${ }^{a}$ \\ Yi Huang ${ }^{b}$ and Yong-Sheng Wei ${ }^{b}$ \\ ${ }^{a}$ Key Laboratory of Synthetic and Natural Functional Molecule Chemistry (Ministry of Education), College \\ of Chemistry and Materials Science, Northwest University, Xi'an 710069, People's Republic of China \\ ${ }^{b}$ Department of Chemistry, Xianyang Normal University, Xianyang, Shaanxi 712000, China
}

\begin{abstract}
Neste trabalho descreve-se a preparação de seis corantes cianina dimetina trinucleares com núcleos de piridina, obtidos a partir da condensação de iodeto de trimetilpiridínio com aldeídos aromáticos heterocíclicos. As propriedades de absorção e fluorescência dos corantes foram estudadas em solventes com polaridades diferentes. O deslocamento hipsocrômico dos máximos de absorção dos corantes foi observado com o aumento da polaridade do solvente. Foram estudadas as propriedades fluorescentes dos corantes em solução e na presença de DNA. Foi observado um aumento significativo do rendimento quântico de fluorescência na presença de DNA para quatro corantes.. Em particular, um dos corantes emite fluorescência fraca no tampão Tris-HCl, apresentando contudo fluorescência intensa na presença de DNA.
\end{abstract}

The preparation of six trinucleus dimethine cyanine dyes with pyridine nucleus obtained by the condensation of trimethylpyridinium iodides with heterocyclic aromatic aldehyde was described. The absorption and fluorescence properties of the dyes were studied in different polarity solvents. Blue shift of the maxima absorption of the dyes was observed with the increase of solvents polarity. The fluorescence properties of the dyes in solution and in presence of DNA were studied. Significant enhancement of the fluorescent quantum yield was observed in four dyes in the presence of DNA. Specially, one of six dyes emitted weak fluorescence in Tris-HCl buffer, but displayed bright fluorescence in the presence of DNA.

Keywords: trinucleus dimethine cyanine dyes, DNA, absorption properties, fluorescence properties, fluorescent dyes

\section{Introduction}

Methine cyanine dyes have been widely researched and explored as sensitizers in photography ${ }^{1}$ and as optical recording materials in laser disk. ${ }^{2}$ Recently, methine cyanine dyes have attracted attention owing to their excellent fluorescence properties ${ }^{3-5}$ as well as their potential applications in probes for DNA in living cells. ${ }^{6-10}$ From the applications of cyanine dyes it is known that the optical properties of cyanine dyes are often influenced by their conjugated systems and the solution environment. Trinucleus dimethine cyanine dyes are large conjugated systems, which contain three heteroaromatic rings joined by two vinyl chains. However the synthesis of trinucleus

\footnotetext{
*e-mail: wanglany@nwu.edu.cn
}

dimethine cyanine dyes and their applications as fluorescent probe were rarely reported. ${ }^{11,12}$ Our previous efforts have been devoted to developing series of cyanine dyes and styryl dyes. ${ }^{13-17}$

In this paper, six trinucleus dimethine cyanine dyes with pyridine nucleus, four dyes of which were novel, were synthesized in water or ethanol via the condensation of appropriate heteroaromatic aldehydes with quaternary salts of heterocyclic compounds containing active methyl groups. The influence of different solvents on spectral properties of the trinucleus dimethine cyanine dyes was studied by UV-Vis and fluorescence spectroscopy. A further objective of this study was to investigate the fluorescence spectral properties of prepared trinucleus dimethine cyanine dyes both in solution and in the DNA presence, exploring their future applications as fluorescence probe. 


\section{Experimental}

\section{General}

All reagents were obtained from commercial sources and used without further purification. All chemicals were of analytical grade. Melting points were taken on a XT-4 micromelting apparatus and uncorrected. IR spectra in $\mathrm{cm}^{-1}$ were recorded on Shimadzu IRPrestige-21 spectrometer and Bruker Equiox-55 spectrometer. ${ }^{1} \mathrm{H}$ NMR spectra were recorded at $400 \mathrm{MHz}$ on a Varian Inova-400 spectrometer and chemical shifts were reported relative to internal $\mathrm{Me}_{4} \mathrm{Si}$. ${ }^{13} \mathrm{C}$ NMR spectra were recorded at $100 \mathrm{MHz}$ on a Varian Inova-400 spectrometer and chemical shifts were reported relative to internal $\mathrm{Me}_{4} \mathrm{Si}$. Elemental analysis was performed with Vario EL-III instrument. The electron impact (EI) mass spectra were recorded at $70 \mathrm{eV}$ with a GCMS-QP2010 system equipped with the solid sample direct insertion probe. The absorption spectra were recorded on a Shimadzu UV-1700 UV-Vis spectrometer. Fluorescence measurements were carried out on a Hitachi F-4500 spectrofluorimeter.

\section{Measurements of the spectral properties of the dyes in different solvents}

The dye stock solutions $\left(5.0 \times 10^{-4} \mathrm{~mol} \mathrm{~L}^{-1}\right.$ in dimethylsulfoxide (DMSO)) were diluted with different solvents and resulted in working solutions of dyes $\left(2.0 \times 10^{-5}\right.$ mol L-1). The absorption spectra were examined at room temperature in different solvents and recorded using $1 \mathrm{~cm}$ quartz cells on a Shimadzu UV-1700 UV-Vis spectrometer. Fluorescence measurements were carried out at room temperature on a Hitachi F-4500 spectrofluorimeter in $1 \mathrm{~cm}$ quartz cells. Fluorescence emission was excited at the maximum of the absorption. The absorption and fluorescence spectral data were listed in Table 1.

Measurements of spectral properties of the dyes in the presence of DNA

Dye stock solutions $\left(2.0 \times 10^{-4} \mathrm{~mol} \mathrm{~L}^{-1}\right)$ were prepared by dissolving the dyes in DMSO and further diluted with Tris- $\mathrm{HCl}$ buffer ( $\mathrm{pH}$ 7.4) to result in working solutions of dyes $\left(1.0 \times 10^{-5} \mathrm{~mol} \mathrm{~L}^{-1}\right)$. Stock solution of DNA was prepared by dissolving salmon sperm DNA in $0.05 \mathrm{~mol} \mathrm{~L}^{-1}$ Tris-HCl buffer. The concentration of DNA in stock solution was $3.1 \times 10^{-3} \mathrm{~mol} \mathrm{~L}^{-1}$ base pairs (bp). The fluorescence of dyes in the presence of DNA was tested by adding $0.5 \mathrm{~mL}$ DNA solution $\left(3.1 \times 10^{-3} \mathrm{~mol} \mathrm{~L}^{-1} \mathrm{bp}\right)$ into $1.0 \mathrm{~mL} 1.0 \times 10^{-5} \mathrm{~mol} \mathrm{~L}^{-1}$ working solutions of dyes. All working solutions were prepared immediately before the experiment.
The absorption spectra were examined at room temperature in different solvents and recorded using $1 \mathrm{~cm}$ quartz cells on a Shimadzu UV-1700 UV-Vis spectrometer. Fluorescence measurements were carried out at room temperature on a Hitachi F-4500 spectrofluorimeter in $1 \mathrm{~cm}$ quartz cells. Fluorescence emission was excited at the maximum of the fluorescence excitation spectrum. The absorption and fluorescence spectral date were listed in Table 2 and Table 3.

\section{Preparation of trimethyl pyridine quaternary salt $\mathbf{2 a}-\mathbf{2 b}$}

A mixture of $3.54 \mathrm{~g}(0.033 \mathrm{~mol}) \mathbf{1 a}$ or $\mathbf{1 b}$ with $4.71 \mathrm{~g}$ $(0.033 \mathrm{~mol}) \mathrm{CH}_{3} \mathrm{I}$ was refluxed for $20 \mathrm{~h}$. After cooling, the product was filtered off and purified by recrystallization from ethanol. Pyridine quaternary salt 2a: 5.1 g, yield 62\%, mp 130-131 ${ }^{\circ}$ C. 2 b: 5.4 g. Yield 66\%, mp 235-236 ${ }^{\circ}$ C.

\section{Preparation of dyes $\mathbf{3 a - 3 b}$}

A mixture of $\mathbf{2 a}$ or $\mathbf{2 b}(0.10 \mathrm{~g}, 0.4 \mathrm{mmol})$, indole3 -carboxaldehyde $(0.15 \mathrm{~g}, 1.0 \mathrm{mmol})$ and 5 drops of piperidine was refluxed for $24 \mathrm{~h}$ in $8 \mathrm{~mL}$ ethanol. After cooling, ether was added and the product was filtered off, washed with ether and recrystallized from ethanol:water $=$ 9:1. Yield: 3a: $0.15 \mathrm{~g}$ (84\%), 3b: $0.16 \mathrm{~g}$ (79\%).

\section{Preparation of dyes $\mathbf{3 c}-\mathbf{3 d}$}

The dyes $\mathbf{3 c - 3 d}$ were synthesized according to a revised literature procedure. ${ }^{12}$ A mixture of $\mathbf{2 a}$ or $\mathbf{2 b}$ (0.10 g, $0.4 \mathrm{mmol}), 1$-methylpyrrole-2-carboxaldehyde $(0.20 \mathrm{~g}, 1.0 \mathrm{mmol})$ and 5 drops of piperidine was refluxed for $20 \mathrm{~h}$ in $5 \mathrm{~mL}$ ethanol. After cooling, ether was added and the product was filtered off, washed with ether and recrystallized from ethanol: water $=9: 1$. Yield: $3 c$ : $0.17 \mathrm{~g}$ (86\%), 3d: $0.15 \mathrm{~g}(76 \%)$.

\section{Preparation of dyes $\mathbf{3 e}-\mathbf{3 f}$}

Quaternary salts $\mathbf{2 a}$ or $\mathbf{2 b}(0.2 \mathrm{~g}, 0.8 \mathrm{mmol})$ and furaldehyde $(0.62 \mathrm{~g}, 6.4 \mathrm{mmol})$ were dissolved in $18 \mathrm{~mL}$ $\mathrm{H}_{2} \mathrm{O}$. $\mathrm{NaOH}(20 \%, 4.6 \mathrm{~mL})$ was added with stirring over $30 \mathrm{~min}$. After $1 \mathrm{~h}$, the product was filtered off, washed with cold water and recrystallized from water. Yield: $\mathbf{3 e}: 0.22 \mathrm{~g}$ (69\%), 3f: $0.27 \mathrm{~g}(83 \%)$.

\section{1-Methyl-2,4-bis[2-(indole-3-yl)vinyl]pyridinium iodide} (3a)

Orange-red crystals with metallic luster, mp $172{ }^{\circ} \mathrm{C}$ (decomposition), ${ }^{1} \mathrm{H}$ NMR (DMSO- $d_{6}, 400 \mathrm{MHz}$ ): $\delta 4.21$ (s, 
$\left.3 \mathrm{H}, \mathrm{N}^{+} \mathrm{CH}_{3}\right), 7.20-7.32(\mathrm{~m}, 6 \mathrm{H}, \mathrm{Ar}-\mathrm{H}, \mathrm{CH}=\mathrm{CH}), 7.52-7.54$ (m, 2H, Ar-H), 7.89 (d, 1H, J $6.8 \mathrm{~Hz}$, pyridine-H), 7.917.92 (m, 1H, Ar-H), 8.10-8.19 (m, 2H, CH=CH), 8.19-8.25 $(\mathrm{m}, 3 \mathrm{H}$, indole- $\mathrm{H}, \mathrm{CH}=\mathrm{CH}), 8.48(\mathrm{~s}, 1 \mathrm{H}$, pyridine- $\mathrm{H})$, $8.54(\mathrm{~d}, 1 \mathrm{H}, J 6.8 \mathrm{~Hz}$, pyridine-H), $11.84(\mathrm{~s}, 1 \mathrm{H}$, indole $\mathrm{N}-\mathrm{H}), 11.96(\mathrm{~s}, 1 \mathrm{H}$, indole $\mathrm{N}-\mathrm{H}) .{ }^{13} \mathrm{C}$ NMR (DMSO- $d_{6}$, $100 \mathrm{MHz}): \delta 43.6,110.2,112.1,113.0,113.1,116.7,117.0$, 117.6, 119.7, 120.0, 120.4, 120.6, 122.3, 122.4, 124.5, 131.1, 131.3, 134.3, 136.1, 136.8, 137.0, 143.5, 152.1. IR $v_{\text {max }} / \mathrm{cm}^{-1}(\mathrm{KBr}) 3400\left(\mathrm{~m}, \mathrm{v}_{=\mathrm{NH}}\right), 3068\left(\mathrm{v}_{=\mathrm{C}-\mathrm{H}}\right), 1597,1552$ $\left(v_{\mathrm{C}=\mathrm{C}}\right), 1517,14921423\left(\mathrm{~s}, \mathrm{v}_{\mathrm{C}=\mathrm{C}}, \mathrm{v}_{\mathrm{C}=\mathrm{N}}\right), 1367,1315,1238$, 1128, $1107\left(\delta_{\mathrm{CH}}\right), 957,744\left(\mathrm{~m}, \delta_{=\mathrm{CH}}\right)$. MS: EI $(70 \mathrm{ev}) \mathrm{m} / \mathrm{z}$ (\%): $361\left(58 \mathrm{M}-\mathrm{CH}_{3} \mathrm{I}\right), 360\left(100 \mathrm{M}-\mathrm{CH}_{3} \mathrm{I}-\mathrm{H}\right), 142$, 127. UV-Vis $\lambda_{\max } / \mathrm{nm}$ (methanol) 465 . Found: $\mathrm{C}, 59.0 ; \mathrm{H}$, $4.43 ; \mathrm{N}, 7.56$. Calc. for $\mathrm{C}_{26} \mathrm{H}_{22} \mathrm{~N}_{3} \mathrm{I} \cdot 3 / 2 \mathrm{H}_{2} \mathrm{O}\left(530.3 \mathrm{~g} \mathrm{~mol}^{-1}\right)$ : C, $58.9 ; \mathrm{H}, 4.72 ; \mathrm{N}, 7.92 \%$.

\section{1-Methyl-2,6-bis[2-(indole-3-yl)vinyl]pyridinium iodide} (3b)

Orange-red crystals with metallic luster, mp $206-207^{\circ} \mathrm{C}$, ${ }^{1} \mathrm{H}$ NMR (DMSO- $\left.d_{6}, 400 \mathrm{MHz}\right): \delta 4.12\left(\mathrm{~s}, 3 \mathrm{H}, \mathrm{N}^{+} \mathrm{CH}_{3}\right.$ ), 7.21-7.29 (m, 6H, Ar-H), 7.51-7.54 (m, 2H, CH=CH), 7.85-7.92 (m, 2H, $\mathrm{CH}=\mathrm{CH}), 8.10-8.24(\mathrm{~m}, 5 \mathrm{H}, \mathrm{Ar}-\mathrm{H}$, pyridine- $\mathrm{H}), 8.48-8.56(\mathrm{~m}, 2 \mathrm{H}$, pyridine- $\mathrm{H}), 11.86(\mathrm{~s}$, $1 \mathrm{H}$, indole $\mathrm{N}-\mathrm{H}), 11.97(\mathrm{~s}, 1 \mathrm{H}$, indole $\mathrm{N}-\mathrm{H}) .{ }^{13} \mathrm{C}$ NMR (DMSO- $d_{6}, 100 \mathrm{MHz}$ ): $\delta 44.0,110.7,112.5,113.3,113.4$, 117.2, 117.4, 118.0, 120.1, 120.4, 120.9, 121.1, 122.7, $122.8,124.7,124.9,131.3,131.5,131.7,134.7,136.4$, 137.1, 137.2, 137.4, 143.9, 152.5. IR $v_{\max } / \mathrm{cm}^{-1}(\mathrm{KBr})$ $3389\left(\mathrm{~m}, \mathrm{v}_{=\mathrm{NH}}\right), 3071\left(\mathrm{v}_{=\mathrm{C}-\mathrm{H}}\right), 1598,1551\left(\mathrm{v}_{\mathrm{C}=\mathrm{C}}\right), 1493$ $1423\left(\mathrm{~s}, \mathrm{v}_{\mathrm{C}=\mathrm{C}}, \mathrm{v}_{\mathrm{C}=\mathrm{N}}\right), 1313,1273,1237,1189,1128\left(\delta_{\mathrm{CH}}\right)$, $956\left(\mathrm{~s}, \mathrm{v}_{=\mathrm{CH}}\right), 809,745\left(\mathrm{~m}, \delta_{=\mathrm{CH}}\right)$. MS: EI $(70 \mathrm{ev}) \mathrm{m} / \mathrm{z}(\%)$ : $361\left(62 \mathrm{M}-\mathrm{CH}_{3} \mathrm{I}\right), 360\left(100 \mathrm{M}-\mathrm{CH}_{3} \mathrm{I}-\mathrm{H}\right), 142,127$. UV-Vis $\lambda_{\max } / \mathrm{nm}$ (methanol) 464. Found: C, 61.50; H, 4.23; $\mathrm{N}, 8.13$. Calc. for $\mathrm{C}_{26} \mathrm{H}_{22} \mathrm{~N}_{3} \mathrm{I}\left(503.3 \mathrm{~g} \mathrm{~mol}^{-1}\right): \mathrm{C}, 61.85 ; \mathrm{H}$, $4.40 ; \mathrm{N}, 8.32 \%$.

\section{1-Methyl-2,4-bis[2-(1-methylpyrrol-2-yl)vinyl]pyridinium iodide $(3 \boldsymbol{c})$}

Red needle crystals, mp $180-181^{\circ} \mathrm{C},{ }^{1} \mathrm{H} \mathrm{NMR}\left(\mathrm{CDCl}_{3}\right.$, $400 \mathrm{MHz}$ ): $\delta 3.70-4.01\left(\mathrm{~m}, 9 \mathrm{H}\right.$, pyrrole $\mathrm{N}-\mathrm{CH}_{3}, \mathrm{~N}^{+} \mathrm{CH}_{3}$ ), 6.20 (s $1 \mathrm{H}$, pyrrole-H), 6.24 (s $1 \mathrm{H}$, pyrrole-H), 6.52 (d, 1H, J $15.2 \mathrm{~Hz}, \mathrm{CH}=\mathrm{CH}$ ), 6.73 (s, 1H, pyrrole-H), 6.83 (s, 3H, pyrrole-H), $7.08(\mathrm{~d}, 1 \mathrm{H}, J 16.0 \mathrm{~Hz}, \mathrm{CH}=\mathrm{CH})$ $7.54(\mathrm{~d}, 1 \mathrm{H}, J 16.0 \mathrm{~Hz}, \mathrm{CH}=\mathrm{CH}), 7.68(\mathrm{~d}, 1 \mathrm{H}, J 6.8 \mathrm{~Hz}$, pyridine-H), $8.03(\mathrm{~d}, 1 \mathrm{H}, J 15.2 \mathrm{~Hz}, \mathrm{CH}=\mathrm{CH}), 8.28(\mathrm{~d}$, $1 \mathrm{H}, J 6.8 \mathrm{~Hz}$, pyridine-H), 8.60 (s, 1H, pyridine-H). ${ }^{13} \mathrm{C}$ NMR (DMSO- $\left.d_{6}, 100 \mathrm{MHz}\right): \delta 34.0,34.1,44.2,109.6$, 109.7, 111.1, 111.3, 112.7, 117.6, 117.9, 119.2, 128.0, 128.1, 128.5, 130.2, 130.2, 130.4, 144.0, 151.6, 151.9. IR $v_{\text {max }} / \mathrm{cm}^{-1}(\mathrm{KBr}) 3440\left(\mathrm{~m}, \mathrm{v}_{=\mathrm{NH}}\right), 3031\left(\mathrm{v}_{\mathrm{=C}-\mathrm{H}}\right), 1597,1547$
$\left(v_{\mathrm{C}=\mathrm{C}}\right), 1520,1409\left(\mathrm{~s}, v_{\mathrm{C}=\mathrm{C}}, v_{\mathrm{C}=\mathrm{N}}\right), 1339,1264,1194,1126$, $1086\left(\delta_{\mathrm{CH}}\right), 971,888,814,710\left(\mathrm{~m}, \delta_{=\mathrm{CH}}\right)$. MS: EI(70 ev) $m / z(\%): 289\left(45 \mathrm{M}-\mathrm{CH}_{3} \mathrm{I}\right), 288\left(100 \mathrm{M}-\mathrm{CH}_{3} \mathrm{I}-\mathrm{H}\right), 142$, 127. UV-Vis $\lambda_{\max } / \mathrm{nm}$ (methanol) 473. Found: C, 53.91; $\mathrm{H}, 3.57$; N, 5.99. Calc. for $\mathrm{C}_{20} \mathrm{H}_{22} \mathrm{~N}_{3} \mathrm{I}\left(431.09 \mathrm{~g} \mathrm{~mol}^{-1}\right)$ : C, $53.77 ; \mathrm{H}, 3.61 ; \mathrm{N}, 6.27 \%$.

1-Methyl-2,6-bis[2-(1-methylpyrrol-2-yl)vinyl]pyridinium iodide (3d)

Red needle, mp $230{ }^{\circ} \mathrm{C}$ (decomposition), ${ }^{1} \mathrm{H}$ NMR $\left(\mathrm{CDCl}_{3}, 400 \mathrm{MHz}\right): \delta 3.86\left(\mathrm{~s}, 6 \mathrm{H}\right.$, pyrrole $\left.\mathrm{N}-\mathrm{CH}_{3}\right), 4.28$ (s, $3 \mathrm{H}, \mathrm{N}^{+} \mathrm{CH}_{3}$ ), 6.21-6.23 (m, 2H, pyrrole-H), $6.79(\mathrm{~s}, 2 \mathrm{H}$, pyridine- $\mathrm{H}), 6.93-6.99(\mathrm{~m}, 4 \mathrm{H}, \mathrm{CH}=\mathrm{CH}$, pyrrole- $\mathrm{H}), 7.50$ $(\mathrm{d}, 2 \mathrm{H}, J 16.0 \mathrm{~Hz}, \mathrm{CH}=\mathrm{CH}), 8.08-8.10(\mathrm{~m}, 3 \mathrm{H}$, pyridine- $\mathrm{H}$, pyrrole-H). ${ }^{13} \mathrm{C}$ NMR (DMSO- $d_{6}, 100 \mathrm{MHz}$ ): $\delta 33.9$, 40.9, 109.5, 112.4, 112.7, 121.2, 128.2, 130.3, 141.1, 153.2. IR $v_{\max } / \mathrm{cm}^{-1}(\mathrm{KBr}) 3446\left(\mathrm{~m}, \mathrm{v}_{=\mathrm{NH}}\right), 3073\left(\mathrm{v}_{=\mathrm{C}-\mathrm{H}}\right)$, $1604,1559\left(v_{\mathrm{C}=\mathrm{C}}\right), 1469,1404\left(\mathrm{~s}, \mathrm{v}_{\mathrm{C}=\mathrm{C}}, v_{\mathrm{C}=\mathrm{N}}\right), 1335,1307$, 1228, 1189, 1144, $1090\left(\delta_{\mathrm{CH}}\right), 948,841,802,730(\mathrm{~m}$, $\left.\delta_{=\mathrm{CH}}\right)$. MS: EI $(70 \mathrm{ev}) \mathrm{m} / z(\%): 289\left(100 \mathrm{M}-\mathrm{CH}_{3} \mathrm{I}\right), 288$ (58 M- $\left.\mathrm{CH}_{3} \mathrm{I}-\mathrm{H}\right), 142,127$. UV-Vis $\lambda_{\max } / \mathrm{nm}$ (methanol) 465. Found: C, 53.88; H, 3.65; N, 6.47. Calc. for $\mathrm{C}_{20} \mathrm{H}_{22} \mathrm{~N}_{3} \mathrm{I}$ (431.09 $\mathrm{g} \mathrm{mol}^{-1}$ ): C, 53.77; H, 3.61; N, 6.27\%.

\section{1-Methyl-2,4-bis[2-(furan-2-yl)vinyl]pyridinium iodide} (3e)

Yellow powder, mp $254-255{ }^{\circ} \mathrm{C},{ }^{1} \mathrm{H}$ NMR $\left(\mathrm{CDCl}_{3}\right.$, $400 \mathrm{MHz}): \delta 4.35\left(\mathrm{~s}, 3 \mathrm{H}, \mathrm{N}^{+} \mathrm{CH}_{3}\right), 6.54-6.55(\mathrm{~m}, 2 \mathrm{H}$, furan-H), 6.91-6.98 (m, 4H, furan- $\mathrm{H}, \mathrm{CH}=\mathrm{CH}), 7.56-$ $7.58(\mathrm{~m}, 2 \mathrm{H}$, furan-H), 7.68-7.82 (m, 3H, $\mathrm{CH}=\mathrm{CH}$, pyridine-H), 8.14 (s, 1H, pyridine-H), $9.10(\mathrm{~d}, 1 \mathrm{H}, J$ $6.8 \mathrm{~Hz}$, pyridine-H). ${ }^{13} \mathrm{C}$ NMR (DMSO- $d_{6}, 100 \mathrm{MHz}$ ): $\delta$ 44.4, 112.8, 115.0, 115.7, 119.8, 120.2, 126.4, 128.3, 144.9, 145.7, 146.0, 150.6, 150.8, 150.9. IR $v_{\max } / \mathrm{cm}^{-1}(\mathrm{KBr}) 3474$ $\left(\mathrm{m}, v_{=\mathrm{NH}}\right), 3083\left(v_{=\mathrm{C}-\mathrm{H}}\right), 1608,1558\left(\mathrm{v}_{\mathrm{C}=\mathrm{C}}\right), 1470,1442(\mathrm{~s}$, $\left.\mathrm{v}_{\mathrm{C}=\mathrm{C}}, \mathrm{v}_{\mathrm{C}=\mathrm{N}}\right), 1386,1330,1301\left(\delta_{\mathrm{CH}}\right) 1253\left(\mathrm{v}_{\text {asC-O-C C }}\right), 1069\left(\mathrm{v}_{\mathrm{sC}-}\right.$ o-c) $, 969,880,751\left(\mathrm{~m}, \delta_{=\mathrm{CH}}\right.$ ). MS: EI (70 ev) $\mathrm{m} / z(\%): 264$ $\left(11 \mathrm{M}-\mathrm{CH}_{3} \mathrm{I}\right), 263\left(53 \mathrm{M}-\mathrm{CH}_{3} \mathrm{I}-\mathrm{H}\right), 142,127$. MS: EI (70 ev) $\mathrm{m} / z(\%): 264\left(11 \mathrm{M}-\mathrm{CH}_{3} \mathrm{I}\right), 263\left(53 \mathrm{M}-\mathrm{CH}_{3} \mathrm{I}-\mathrm{H}\right)$, 142, 127. UV-Vis $\lambda_{\max } / \mathrm{nm}$ (methanol) 397. Found: C, 53.64; $\mathrm{H}, 3.60 ; \mathrm{N}, 3.60$. Calc. for $\mathrm{C}_{18} \mathrm{H}_{16} \mathrm{NIO}_{2}\left(405.02 \mathrm{~g} \mathrm{~mol}^{-1}\right)$ : C, $53.35 ; \mathrm{H}, 3.98 ; \mathrm{N}, 3.46 \%$.

\section{1-Methyl-2,6-bis[2-(furan-2-yl)vinyl]pyridinium iodide (3f)}

Khaki-colored powder, mp 214-215 ${ }^{\circ} \mathrm{C},{ }^{1} \mathrm{H}$ NMR $\left(\mathrm{CDCl}_{3}, 400 \mathrm{MHz}\right): \delta 4.37$ (s, 3H, $\left.\mathrm{N}^{+} \mathrm{CH}_{3}\right), 6.54-6.55(\mathrm{~m}$, $2 \mathrm{H}, \mathrm{CH}=\mathrm{CH}), 6.93-6.94(\mathrm{~m}, 2 \mathrm{H}$, furan-H), 7.21-7.27 (m, $2 \mathrm{H}, \mathrm{CH}=\mathrm{CH}), 7.50-7.56(\mathrm{~m}, 4 \mathrm{H}$, furan-H), $8.08(\mathrm{~d}, 2 \mathrm{H}$, $J 8.8 \mathrm{~Hz}$, pyridine-H), $8.28(\mathrm{t}, 1 \mathrm{H}, J 8.8 \mathrm{~Hz}$, pydidine-H). ${ }^{13} \mathrm{C}$ NMR (DMSO-d, $100 \mathrm{MHz}$ ): $\delta$ 41.1, 112.7, 115.4, 
115.5, 122.8, 128.4, 142.3, 145.7, 150.6, 152.2. IR $v_{\max } / \mathrm{cm}^{-1}$ $(\mathrm{KBr}) 3479\left(\mathrm{~m}, \mathrm{v}_{=\mathrm{NH}}\right), 3061\left(\mathrm{v}_{=\mathrm{C}-\mathrm{H}}\right), 1602,1561\left(\mathrm{v}_{\mathrm{C}=\mathrm{C}}\right), 1463$, $1384\left(\mathrm{~s}, \mathrm{v}_{\mathrm{C}=\mathrm{C}}, \mathrm{v}_{\mathrm{C}=\mathrm{N}}\right), 1305\left(\delta_{\mathrm{CH}}\right) 1247\left(\mathrm{v}_{\mathrm{asC}-\mathrm{O}-\mathrm{C}}\right) 1068\left(\mathrm{v}_{\mathrm{sC}-\mathrm{O}-\mathrm{C}}\right)$, 951, 982, 878, $757\left(\mathrm{~m}, \delta_{=\mathrm{CH}}\right)$. MS: EI (70 ev) $\mathrm{m} / z(\%): 264$ $\left(8 \mathrm{M}-\mathrm{CH}_{3} \mathrm{I}\right), 263\left(39 \mathrm{M}-\mathrm{CH}_{3} \mathrm{I}-\mathrm{H}\right), 142,127$. UV-Vis $\lambda_{\max } / \mathrm{nm}$ (methanol) 397. Found: C, 53.31; H, 3.60; N, 3.76. Calc. for $\mathrm{C}_{18} \mathrm{H}_{16} \mathrm{NIO}_{2}\left(405.02 \mathrm{~g} \mathrm{~mol}^{-1}\right): \mathrm{C}, 53.35 ; \mathrm{H}$, $3.46 ; \mathrm{N}, 3.98 \%$.

\section{Results and Discussion}

\section{Synthesis}

The trinucleus dimethine cyanine dye was synthesized via the reaction of heteroaromatic aldehydes with the quaternary ammonium salt of 1,2,4-trimethyl pyridine quaternary salt or 1,2,6- trimethyl pyridine quaternary salt (Scheme 1). In all cases investigated, we found that the formation reactions of trinucleus dimethine cyanine dyes with pyridine nucleus proceeded efficiently under catalysis of piperidine or $\mathrm{NaOH}$, and the better and purer yields were obtained in ethanol for $\mathbf{3 a - 3 d}$ and in water for $\mathbf{3 e - 3 f}$. For example, the yield of $\mathbf{3 d}$ could reach $86 \%$ in ethanol, and $65 \%$ in water. ${ }^{12}$ The yield of $\mathbf{3 f}$ could reach $83 \%$ in water, but in ethanol $\mathbf{3 f}$ could hardly be obtained. Because in organic solvents furaldehyde reacted with quaternary salt so quickly that the reaction could not be controlled, and there would be serious side reactions. In the synthesis of dyes 3a-3f , the required reaction time of heterocyclic aromatic aldehydes with trimethylpyridinium iodides was furaldehyde (30 min) < 1-methylpyrrole-2-carboxaldehyde $(20 \mathrm{~h})<$ indole-3-carboxaldehyde $(24 \mathrm{~h})$, thereby the reaction activity of heterocyclic aromatic aldehydes was furaldehyde $>1$-methylpyrrole-2-carboxaldehyde $>$ indole3 -carboxaldehyde. From the structure it was also suggested that the electron-withdrawing ability of the group attached to aldehyde group was $=\mathrm{C}-\mathrm{O}>=\mathrm{C}-\mathrm{N}>=\mathrm{C}-\mathrm{C}=$, leading to the positive charge density of carbon in aldehyde group was furaldehyde $>1$-methylpyrrole-2-carboxaldehyde $>$ indole-3-carboxaldehyde. The larger the positive charge density of carbon in aldehyde group is, the higher the reaction activity of heterocyclic aromatic aldehyde with trimethylpyridinium iodides is.

\section{Spectral properties of the dyes in different solvents}

Figure 1 gives the absorption maxima $\left(\lambda_{\max }\right)$ of six trinucleus dimethine cyanine dyes in different solvents (their dielectric constant: $\mathrm{CHCl}_{3} 4.9$, EtOH 24.6, $\mathrm{MeOH}$ 32.6, dimethylformamide $38.3, \mathrm{H}_{2} \mathrm{O}$ 78.4). From Figure 1 it could be found that the $\lambda_{\text {max }}$ of $\mathbf{3 a}, \mathbf{3 b}, \mathbf{3} \mathbf{c}$ and $\mathbf{3 d}$ was longer than the $\lambda_{\text {max }}$ of $\mathbf{3 e}$ and $\mathbf{3 f}$. The reason suggested here was that dyes 3a-3f were all D- $\pi$-A molecules, in dyes $\mathbf{3 a - 3 d}$ the electron donor was $\mathrm{N}$ of indole or pyrrole ring, and the electron donor was $\mathrm{O}$ of furan ring in dyes $\mathbf{3 e - 3 f}$, and the electron acceptor of six dyes was all $\mathrm{N}^{+}$of pyridinium. The stronger was electron-donating capability of electron donor, the longer was the $\lambda_{\max }$ of dyes under the same electron-withdrawing capability of electron acceptor. The electron-donating capability of $\mathrm{N}$ situated indole or pyrrole<smiles>Cc1ccnc(C)c1</smiles>

$1 \mathrm{~b}$

2b

3a, 3b: Ar = indole-3-carboxaldehyde

3c, 3d: $\mathrm{Ar}=1$-methylpyrrole-2-carboxaldehyde

3e, 3f: $\mathrm{Ar}=$ furaldehyde 
ring was stronger than that of $\mathrm{O}$ situated furan ring, so the $\lambda_{\max }$ of $\mathbf{3 a - 3} \mathbf{d}$ was longer than the $\lambda_{\text {max }}$ of $\mathbf{3 e - 3 \mathbf { f }}$. It could be also found that with the increasing of solvent polarity the $\lambda_{\max }$ of the dyes decreased. The effect of the solvent polarity on the absorption maximum could be illustrated by interactions between the dye molecules and the solvents, as the interactions made the ground state of dye more stable by forming hydrogen bonds. ${ }^{18,19}$

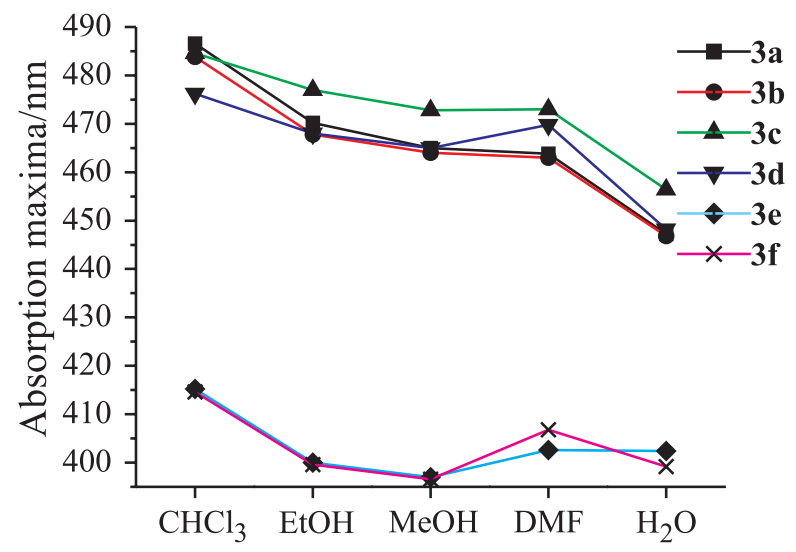

Figure 1. Solvatochromic shifts for the $\lambda_{\max }$ of six trinucleus dimethincyanine dyes in five kinds of solvents.

The absorption, excitation maxima $\left(\lambda_{\text {ex }}\right)$, fluorescence maxima emission $\left(\lambda_{\text {em }}\right)$ of the dyes are summarized in Table 1. The dyes exhibited fluorescence properties at room temperature. Their fluorescence maxima were located at $502-565 \mathrm{~nm}$. Compared with the absorption maxima of the dyes, the emission spectra were shifted to the red by $69-140 \mathrm{~nm}$ (Stokes shift). The stokes shift of six dyes were all large, this might be attributed to an excited-state intramolecular charge transfer between the donor and acceptor in the dyes. Large stokes shift could help to reduce self-quenching and measurement error by excitation light and scattered light. ${ }^{20}$ The fluorescence quantum yield of six dyes was in the region 0.0001-0.0781 in different solvents. From Table 1 it could be found that the order of fluorescence quantum yield was $\mathbf{3 a}, \mathbf{3 b}>\mathbf{3 c}, \mathbf{3 d}$. The possible reason was that the conjugated system of $\mathbf{3 a}, \mathbf{3} \mathbf{b}$ was larger than that of $\mathbf{3 c}, \mathbf{3 d}$. We also found the order of fluorescence quantum yield was $\mathbf{3 a}>\mathbf{3 b}$ and $\mathbf{3} \mathbf{c}>\mathbf{3 d}$. The cause lay in the fact that two D- $\pi$-A system in $\mathbf{3 b}$ and $\mathbf{3 d}$ was in opposite orientation, which made their conjugated system became small. It could be found that the fluorescence performance of $\mathbf{3 e}$ and $\mathbf{3 f}$ was complex, because oxygen of furan ring was of both electron-donating and electron-acceptor effect. And there was also influence of solvents on the fluorescence quantum yield of these dyes. Further investigation of the influence of solvents on the fluorescence quantum yield of the dyes is in progressing.
Table 1. The absorption and fluorescence spectral characteristics of dyes 3a-3f in different solvents

\begin{tabular}{|c|c|c|c|c|c|}
\hline & $\lambda_{\max } / \mathrm{nm}$ & $\lambda_{\mathrm{ex}} / \mathrm{nm}$ & $\lambda_{\mathrm{em}} / \mathrm{nm}$ & $\begin{array}{c}\text { Stokes } \\
\text { shift }\end{array}$ & $\Phi_{\mathrm{F}}$ \\
\hline \multicolumn{6}{|c|}{ Methanol } \\
\hline $3 \mathbf{a}$ & 465 & 465 & 550 & 85 & 0.0538 \\
\hline $3 \mathbf{b}$ & 464 & 464 & 551 & 87 & 0.0310 \\
\hline $3 c$ & 473 & 473 & 559 & 86 & 0.0031 \\
\hline $3 d$ & 465 & 465 & 556 & 91 & 0.0027 \\
\hline $3 e$ & 397 & 397 & 517 & 120 & 0.0289 \\
\hline $3 f$ & 397 & 397 & 508 & 112 & 0.0115 \\
\hline \multicolumn{6}{|c|}{ Ethanol } \\
\hline $3 \mathbf{a}$ & 470 & 470 & 552 & 82 & 0.0781 \\
\hline $3 \mathbf{b}$ & 468 & 467 & 550 & 82 & 0.0689 \\
\hline $3 c$ & 477 & 477 & 561 & 84 & 0.0191 \\
\hline 3d & 468 & 468 & 560 & 92 & 0.0039 \\
\hline $3 \mathbf{e}$ & 400 & 400 & 518 & 118 & 0.0029 \\
\hline $3 f$ & 400 & 400 & 540 & 140 & 0.0028 \\
\hline \multicolumn{6}{|c|}{ Chloroform } \\
\hline $3 \mathbf{a}$ & 487 & 487 & 556 & 70 & 0.0470 \\
\hline $3 b$ & 484 & 484 & 557 & 73 & 0.0403 \\
\hline $3 c$ & 485 & 484 & 559 & 74 & 0.0098 \\
\hline $3 d$ & 476 & 476 & 558 & 82 & 0.0023 \\
\hline $3 e$ & 415 & 415 & 502 & 87 & 0.0110 \\
\hline $3 f$ & 415 & 415 & 509 & 94 & 0.0037 \\
\hline \multicolumn{6}{|c|}{ Dimetilformamida } \\
\hline $3 \mathbf{a}$ & 464 & 464 & 557 & 93 & 0.0298 \\
\hline $3 b$ & 463 & 463 & 556 & 93 & 0.0275 \\
\hline $3 c$ & 473 & 473 & 563 & 90 & 0.0060 \\
\hline 3d & 470 & 470 & 565 & 95 & 0.0008 \\
\hline $3 e$ & 403 & 402 & 532 & 129 & 0.0148 \\
\hline $3 f$ & 407 & 407 & 518 & 111 & 0.0052 \\
\hline \multicolumn{6}{|c|}{ Water } \\
\hline $3 \mathbf{a}$ & 447 & 447 & 554 & 107 & 0.0008 \\
\hline $3 \mathbf{b}$ & 447 & 447 & 553 & 106 & 0.0008 \\
\hline $3 c$ & 456 & 456 & 562 & 106 & 0.0003 \\
\hline 3d & 448 & 448 & 541 & 93 & 0.0001 \\
\hline $3 \mathbf{e}$ & 402 & 402 & 529 & 127 & 0.0032 \\
\hline $3 f$ & 399 & 399 & 515 & 116 & 0.0016 \\
\hline
\end{tabular}

${ }^{a}$ The fluorescence quantum yields of the dyes were determined by the reference standard (rhodamine B $\Phi_{\mathrm{F}}=0.49$ in ethanol at $25^{\circ} \mathrm{C}$ )..$^{21}$

\section{Spectral properties of the dyes in the presence of DNA}

The spectral properties of the dyes in the presence of DNA are summarized in Table 2 and Table 3 . The $\lambda_{\text {max }}$ of DNA-dye solution was situated at $401-458 \mathrm{~nm}$ and showed a slight red shift relative to the corresponding maxima of 
Table 2. Spectral characteristics of dyes $\mathbf{3 a - 3 f}$ in buffer

\begin{tabular}{lccccc}
\hline Dye & \multicolumn{3}{c}{ in buffer } \\
\cline { 2 - 6 } & $\lambda_{\text {max }}(\mathrm{nm})$ & $\varepsilon^{\text {free }} \times 10^{-4}\left(\mathrm{dm}^{3} \mathrm{~mol}^{-1} \mathrm{~cm}^{-1}\right)$ & $\lambda_{\text {ex }}(\mathrm{nm})$ & $\lambda_{\text {em }}(\mathrm{nm})$ & 565 \\
3a & 447 & 2.2 & 445 & 560 & 0.0235 \\
3b & 447 & 2.1 & 445 & 564 & 0.0041 \\
3c & 456 & 5.5 & 453 & - & 0.0042 \\
3d & 448 & 4.8 & 448 & 519 & - \\
3e & 402 & 3.8 & 406 & 504 & 0.0557 \\
3f & 399 & 4.2 & 406 & 0.0323 \\
\hline
\end{tabular}

${ }^{a}$ The fluorescence quantum yields of the dyes were determined by the reference standard (rhodamine $\mathrm{B} \Phi_{\mathrm{F}}=0.49$ in ethanol at $25^{\circ} \mathrm{C}$ ). ${ }^{21}$

Table 3. Spectral characteristics of dyes $\mathbf{3 a - 3 f}$ in presence of DNA

\begin{tabular}{|c|c|c|c|c|c|c|}
\hline \multirow{2}{*}{ Dye } & \multicolumn{5}{|c|}{ in DNA presence } & \multirow{2}{*}{$\Phi_{\mathrm{F}}^{\mathrm{DNA}} / \Phi_{\mathrm{F}}^{\text {free }}$} \\
\hline & $\lambda_{\max }(\mathrm{nm})$ & $\varepsilon^{\mathrm{DNA}} \times 10^{-4}\left(\mathrm{dm}^{3} \mathrm{~mol}^{-1} \mathrm{~cm}^{-1}\right)$ & $\lambda_{\mathrm{ex}}(\mathrm{nm})$ & $\lambda_{\mathrm{em}}(\mathrm{nm})$ & $\Phi_{\mathrm{F}}^{\mathrm{DNA}}$ & \\
\hline $3 \mathbf{a}$ & 455 & 3.2 & 445 & 545 & 0.2242 & 9.5 \\
\hline $\mathbf{3 b}$ & 454 & 6.2 & 445 & 545 & 0.1291 & 31.6 \\
\hline $3 c$ & 458 & 8.5 & 453 & 555 & 0.0791 & 18.9 \\
\hline 3d & 449 & 5.1 & 448 & 553 & 0.0187 & - \\
\hline $3 e$ & 403 & 3.8 & 406 & 515 & 0.0553 & 1.0 \\
\hline $3 f$ & 401 & 4.2 & 406 & 503 & 0.0336 & 1.0 \\
\hline
\end{tabular}

${ }^{\mathrm{a}}$ The fluorescence quantum yields of the dyes were determined by the reference standard (rhodamine $\mathrm{B} \Phi_{\mathrm{F}}=0.49$ in ethanol at $25^{\circ} \mathrm{C}$ ). ${ }^{21}$

free dyes in buffer. The molar extinction coefficients for dyes 3a-3d were increased in the presence of DNA, and were in the range from $3.2 \times 10^{4}$ to $8.5 \times 10^{4} \mathrm{~L} \mathrm{~mol}^{-1} \mathrm{~cm}^{-1}$. However, for dyes $\mathbf{3 e}$ and $\mathbf{3 f}$ the values of molar extinction coefficients were unchanged relative to free dyes, which were $3.8 \times 10^{4}$ and $4.2 \times 10^{4} \mathrm{~L} \mathrm{~mol}^{-1} \mathrm{~cm}^{-1}$, respectively.

The fluorescence emission maxima of DNA-dyes were located at 503-555 nm, and showed a slight blue shift relative to free dyes in solution. Stokes shift values for the DNA-dyes were in the range of 97-109 $\mathrm{nm}$. Moreover, the fluorescence intensity of dyes $\mathbf{3 a - 3 \mathbf { c }}$ was greatly increased in the presence of DNA. Compared with free dyes, the quantum yields of DNA-dyes were up to 9.5 times for dye $\mathbf{3 a}$, up to 31.6 times for dye $\mathbf{3 b}$ (Figure 2) and up to 18.9 times for dye $\mathbf{3 c}$. Specially, the quantum yields of DNA-dye $\mathbf{3 a}$ was the highest in six dyes. It was noteworthy that free dye $\mathbf{3 d}$ could not be detected significantly fluorescence in buffer, but DNA-dye $\mathbf{3 d}$ showed great fluorescence quantum yields. The fluorescence enhancement of trinucleus dimethine cyanine dyes bound to DNA was attributable to the fact that on photoexcitation a lack of free rotation around the internuclear bridge made isomerisation around the $\mathrm{C}-\mathrm{C}$ bonds of the methine chain difficult; and subsequently nonradiative deactivation of the excited state was not possible, causing the dye to fluoresce. ${ }^{22,23}$ Upon binding with DNA, 3a-3d maintained

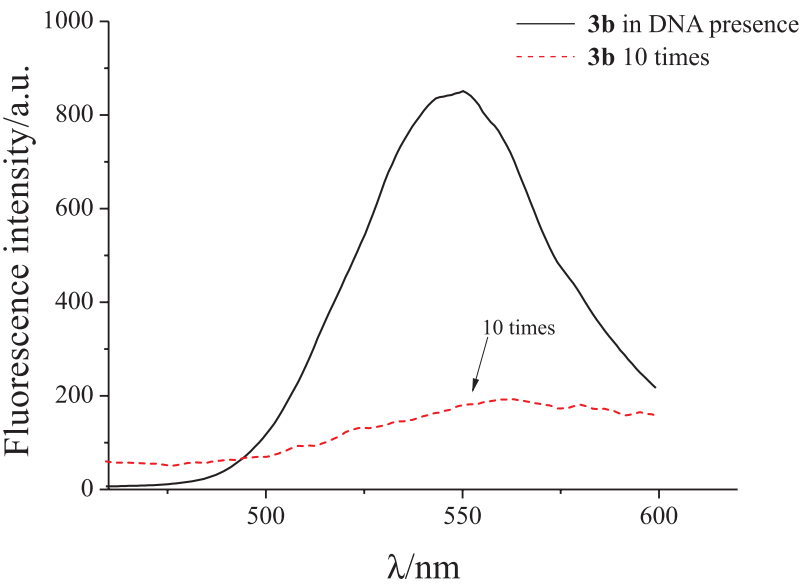

Figure 2. Fluorescence spectra of $\mathbf{3 b}$ in buffer, in the presence of different concentration of DNA.

their high Stokes shift and showed a red shift, owing to a more efficient ICT in the excited state between the terminal heterocyclic aromatic and the pyridimium group. ${ }^{24,25}$

\section{Conclusions}

Six trinucleus dimethine cyanine dyes with pyridine nucleus were synthesized and isolated in $69-86 \%$ yield with piperidine or $\mathrm{NaOH}$ as catalyst. 
The absorption maxima of the dyes were located at $397-487 \mathrm{~nm}$ in different solvents, and with the increase of solvents polarity the maximum absorption wavelength of these dyes had a blue-shift. The fluorescence maxima of the dyes in different solvents were basically located at $502-565 \mathrm{~nm}$, and the fluorescence quantum yield of six dyes was in the region 0.0001-0.0781 in different solvents.

The absorption maxima of the dyes in the presence of DNA were situated at 401-458 nm and showed a slight red shift relative to free dyes. The fluorescence maxima of DNA-dyes were located at $503-555 \mathrm{~nm}$, and showed a slight blue shift relative to free dyes. The fluorescent quantum yields of the DNA-dyes 3a-3c were up to 9.5-31.6 times higher than that of free dyes. Specially, free dye 3d emitted weak fluorescence in buffer, but DNA-dye 3d showed great fluorescence quantum yields. Therefore dyes $\mathbf{3 a - 3 d}$ could be proposed as fluorescent dyes for DNA detection.

\section{Supplementary Information}

Supplementary data are available free of charge at http://jbcs.sbq.org.br, as PDF file.

\section{Acknowledgements}

We appreciate the financial support for this research by a grant from the Natural Science Foundation of Shaanxi Province (No. SJ08B04), the Special Science Research Foundation of Education Committee (No. 08JK458), NWU Excellent Doctoral Dissertation Foundation (No. 08YYB04) and NWU Graduate Cross-discipline Funds (No. 09YJC20).

\section{References}

1. Karatsu, T.; Yanai, M.; Yagai, S.; Mizukami, J.; Urano, T.; Kitamura, A.; J. Photochem. Photobiol., A 2005, 170, 123.

2. Usami, T.; Asanuma, N.; Yamakawa, K.; JP Pat 265,076 2000.

3. Kovalska, V.; Volkova, K.; Losytskyy, M.; Tolmachev, O.; Balanda, A.; Yarmoluk, S.; Spectrochim. Acta, Part A 2006, 65,271 .

4. Deligeorgiev, T.; Gadjev, N.; Vasilev, A.; Maximova, V.; Timcheva, I.; Katerinopoulos, H.; Dyes Pigm. 2007, 75, 466.
5. Kovalska, V.; Kryvorotenko, D.; Balanda, A.; Losytskyy, M.; Tokar, V.; Yarmoluk, S.; Dyes Pigm. 2005, 67, 47.

6. Karlsson, H.; Bergqvist, M.; Lincoln, P.; Westman, G.; Bioorg. Med. Chem. 2004, 12, 2369.

7. Timtcheva, I.; Maximova, V.; Deligeorgiev, T.; Zaneva, D.; Ivanov, I.; J. Photochem. Photobiol., A 2000, 130, 7.

8. Hilal, H.; Taylor, J.; Dyes Pigm. 2007, 75, 483.

9. Rosania, G. R.; Lee, J. W.; Ding, L. Yoon, H. S.; Chang, Y. T.; J. Am. Chem. Soc. 2003, 125, 1130.

10. Li, Q.; Kim, Y.; Namm, J.; Kulkarni, A.; Rosania, G.. R.; Ahn, Y. H.; Chang, Y. T.; Chem. Biol. 2006, 13, 615.

11. Vincenza, B.; Daniele, F.; Condorelli, C.; Giuseppe, M.; Bioorg. Med. Chem. 2002, 10, 2899.

12. Maria, F.; Cosimo, G. F.; Giuseppe, I.; Giuseppe, M.; Eur. J. Org. Chem. 2002, 145.

13. Wang, L. Y.; Zhang, X. G.; Shi, Y. P.; Zhang, Z. X.; Dyes Pigm. 2004, 62, 21.

14. Wang, L. Y.; Zhang, X. G.; Li, F. M.; Zhang, Z. X.; Synth. Commun. 2004, 34, 1.

15. Zhang, Z. X.; Zhang, Y. J.; Hao, J. X.; Li, C. E.; Sci. China, Ser. B: Chem. 1995, 25, 689.

16. Zhang, X .H.; Wang, L. Y.; Zhai, G.. H.; Wen, Z. Y.; Zhang, Z. X.; Bull. Korean Chem. Soc. 2007, 28, 12.

17. Huang, W.; Wang, L. Y.; Fu, Y. L.; Liu, J. Q.; Tao, Y. N.; Fan, F. L.; Zhai, G.. H.; Wen, Z. Y.; Bull. Korean Chem. Soc. 2009, 30,3 .

18. Pham, W.; Lai, W. F.; Weissleder, R.; Tung, C. H.; Bioconjugate Chem. 2003, 14, 1048.

19. Mishra, A.; Behera, R. K.; Behera, P. K.; Mishra, B. K.; Behera, G. B.; Chem. Rev. 2000, 100, 1973; Ibrahim, A. Z.; Al-Ansari, I.; Bull. Soc. Chim. Fr. 1997, 134, 593.

20. Zhang, Z.; Achilefu, S.; Org. Lett. 2004, 6, 2067.

21. Casey, K. G.; Quitevis, E. L.; J. Phys. Chem. 1988, 92, 6590.

22. Carlsson, C.; Larsson, A.; Jonsson, M.; Albinsson, B.; J. Phys. Chem. 1994, 98, 10313.

23. Anikovsky, M.Y.; Tatikolov, A. S.; Shvedove, L. A.; Kuzmin V. A.; Russ. Chem. Bull. 2001, 50, 1190.

24. Neto, B. A. D.; Lápis, A. A. M.; Mancilha, F. S.; Vasconcelos, I. B.; Thum, C.; Basso, L. A.; Santos, D. S.; Dupont, J.; Org. Lett. 2007, 20, 4001.

25. Neto, B. A. D.; Lápis, A. A. M.; Molecules 2009, 14, 1725.

Submitted: April 17, 2010

Published online: August 10, 2010 


\title{
Synthesis, Absorption and Fluorescence Spectral Characteristics of Trinucleus Dimethine Cyanine Dyes as Fluorescent Probes for DNA Detection
}

\author{
Jun-Jie Su, ${ }^{a}$ Lan-Ying Wang, ${ }^{* a}{ }^{a}$ Xiang-Han Zhang, ${ }^{a}$ Yi-Le Fu, ${ }^{a}$ \\ Yi Huang ${ }^{b}$ and Yong-Sheng Wei ${ }^{b}$
}

${ }^{a}$ Key Laboratory of Synthetic and Natural Functional Molecule Chemistry (Ministry of Education), College of Chemistry and Materials Science, Northwest University, Xi'an 710069, People's Republic of China

${ }^{b}$ Department of Chemistry, Xianyang Normal University, Xianyang, Shaanxi 712000, China

For Fluorescence emission of 3a-3f in buffer, in the presence of DNA see Figure S1-S6. For ${ }^{1} \mathrm{H}$ NMR, ${ }^{13} \mathrm{C}$ NMR and IR see Figure S6-S24.

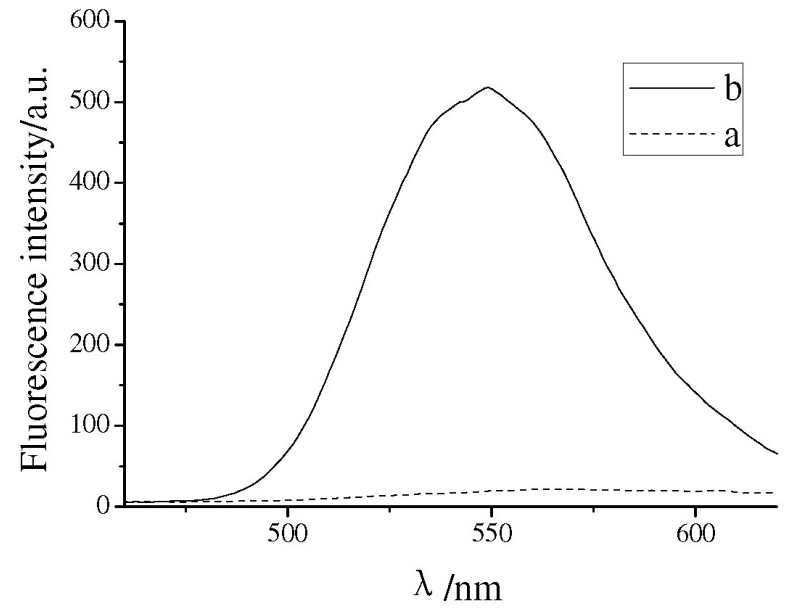

Figure S1. Fluorescence emission of $\mathbf{3 a}$ in buffer, in the presence of DNA. a: $\mathbf{3 a}$ in buffer. $\mathbf{b}: \mathbf{3 a}$ in the presence of DNA.

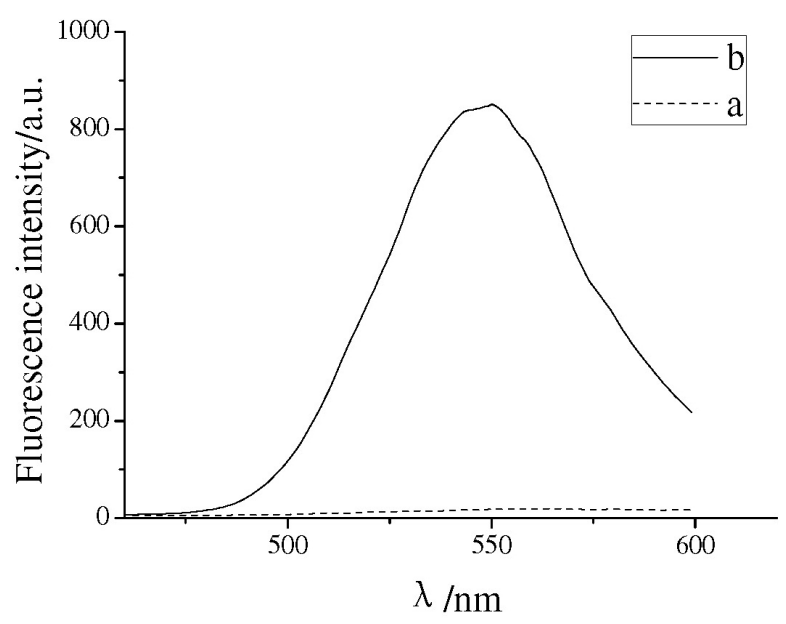

Figure S2. Fluorescence emission of $\mathbf{3 b}$ in buffer, in the presence of DNA. a: $\mathbf{3 b}$ in buffer. $\mathbf{b}: \mathbf{3 b}$ in the presence of DNA.

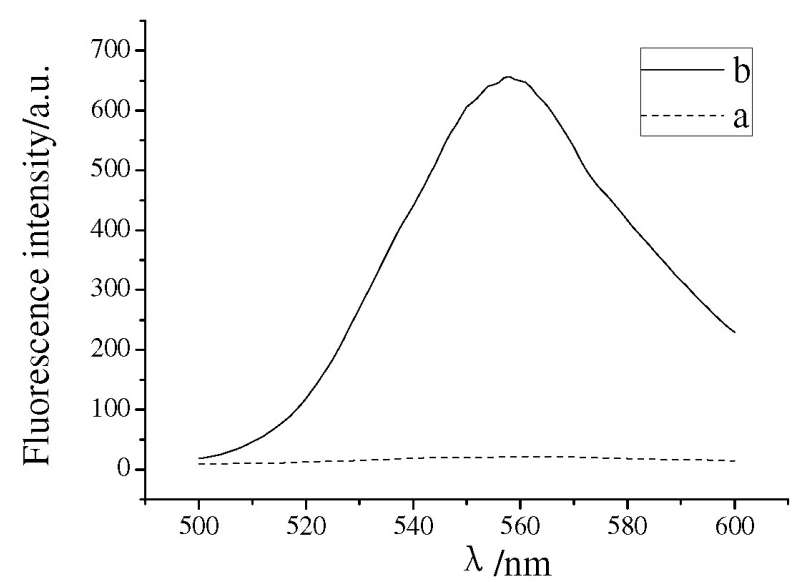

Figure S3. Fluorescence emission of $\mathbf{3 c}$ in buffer, in the presence of DNA. a: $\mathbf{3} \mathbf{c}$ in buffer. b: $\mathbf{3} \mathbf{c}$ in the presence of DNA.

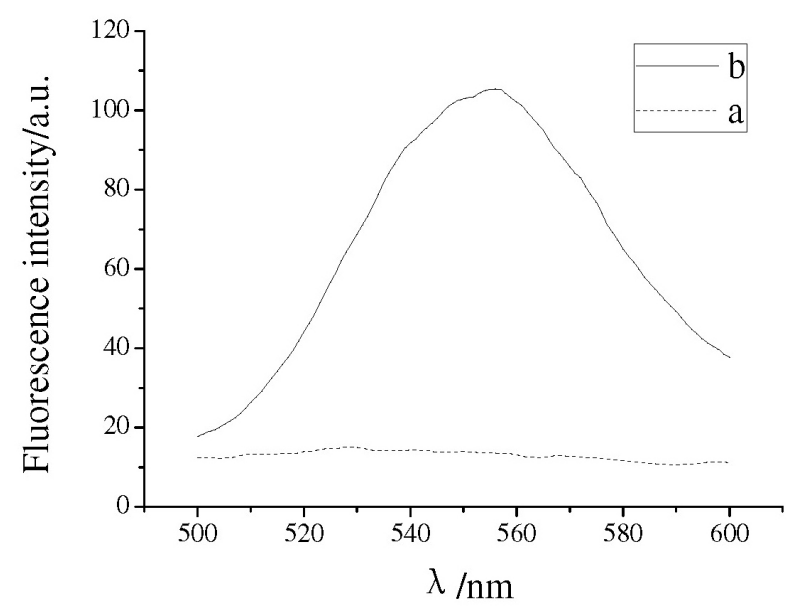

Figure S4. Fluorescence emission of $\mathbf{3 d}$ in buffer, in the presence of DNA. a: $\mathbf{3 d}$ in buffer. b: $\mathbf{3 d}$ in the presence of DNA.

*e-mail: wanglany@nwu.edu.cn 


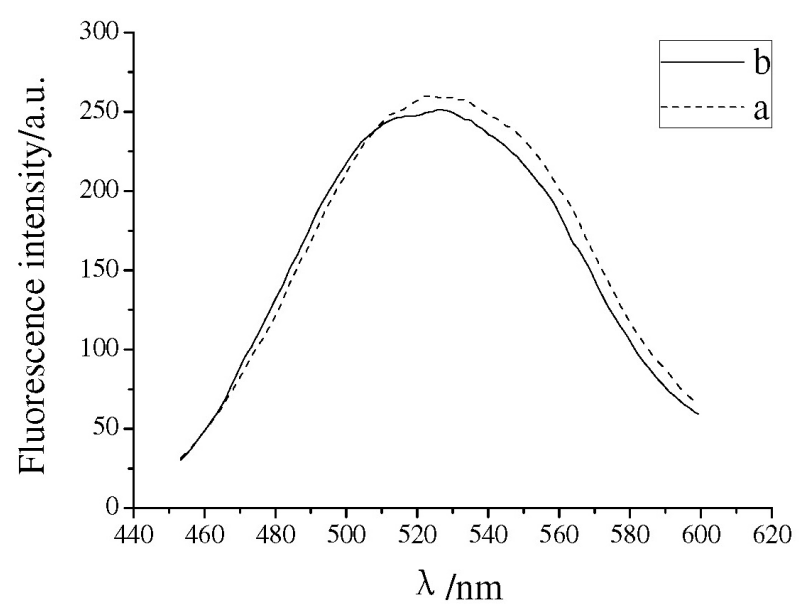

Figure S5. Fluorescence emission of $\mathbf{3 e}$ in buffer, in the presence of DNA. $a: 3 e$ in buffer. b: $\mathbf{3 e}$ in the presence of DNA.

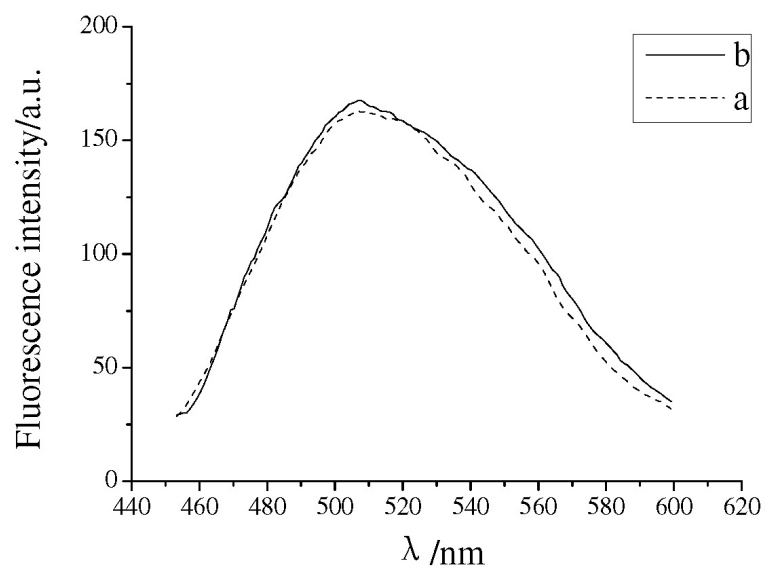

Figure S6. Fluorescence emission of $\mathbf{3 f}$ in buffer, in the presence of DNA. a: $\mathbf{3 f}$ in buffer. b: $\mathbf{3 f}$ in the presence of DNA.

Trinucleus dimethine cyanine dye 3 a

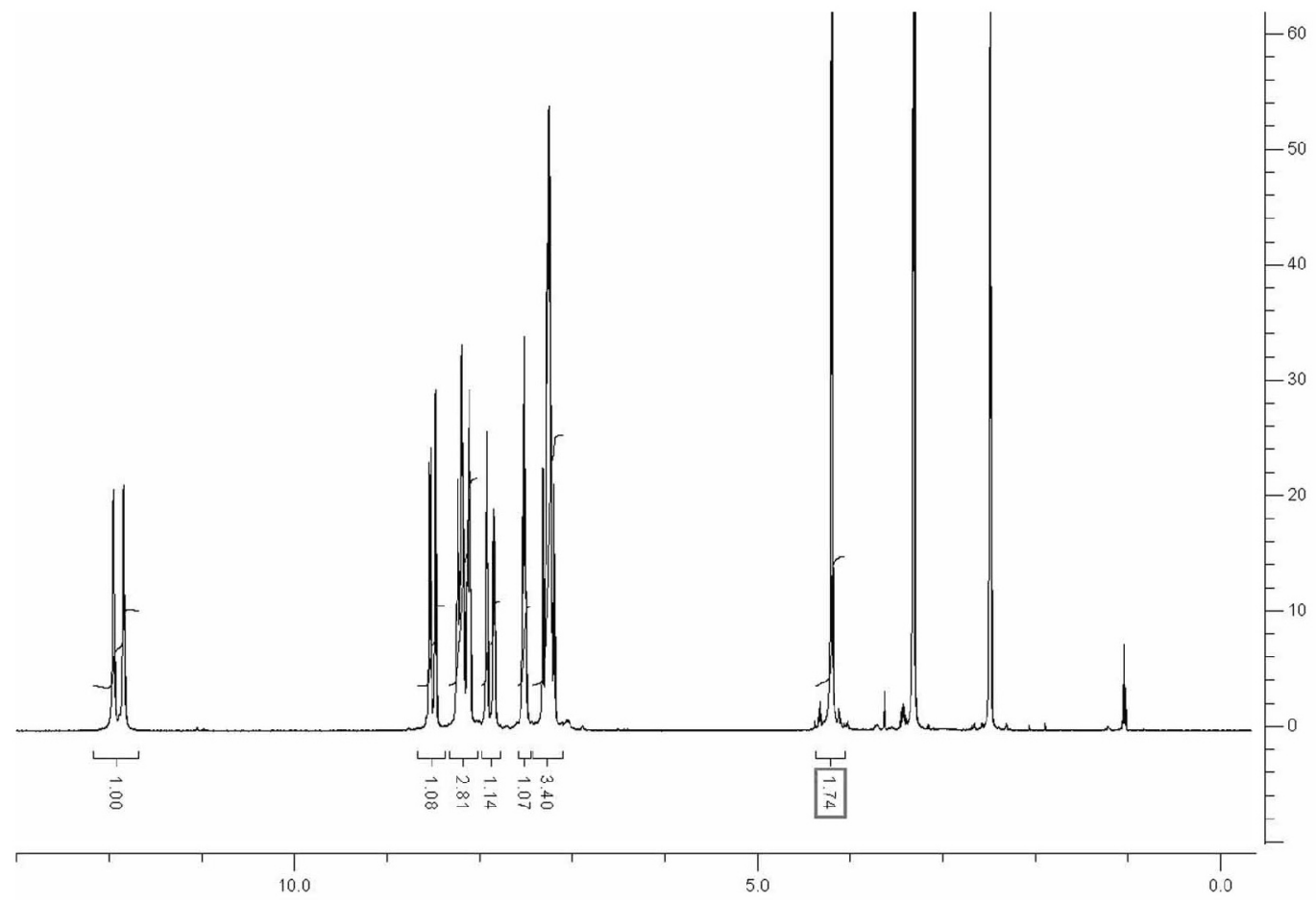

Figure S7. 'H NMR spectrum of $\mathbf{3 a}$. 


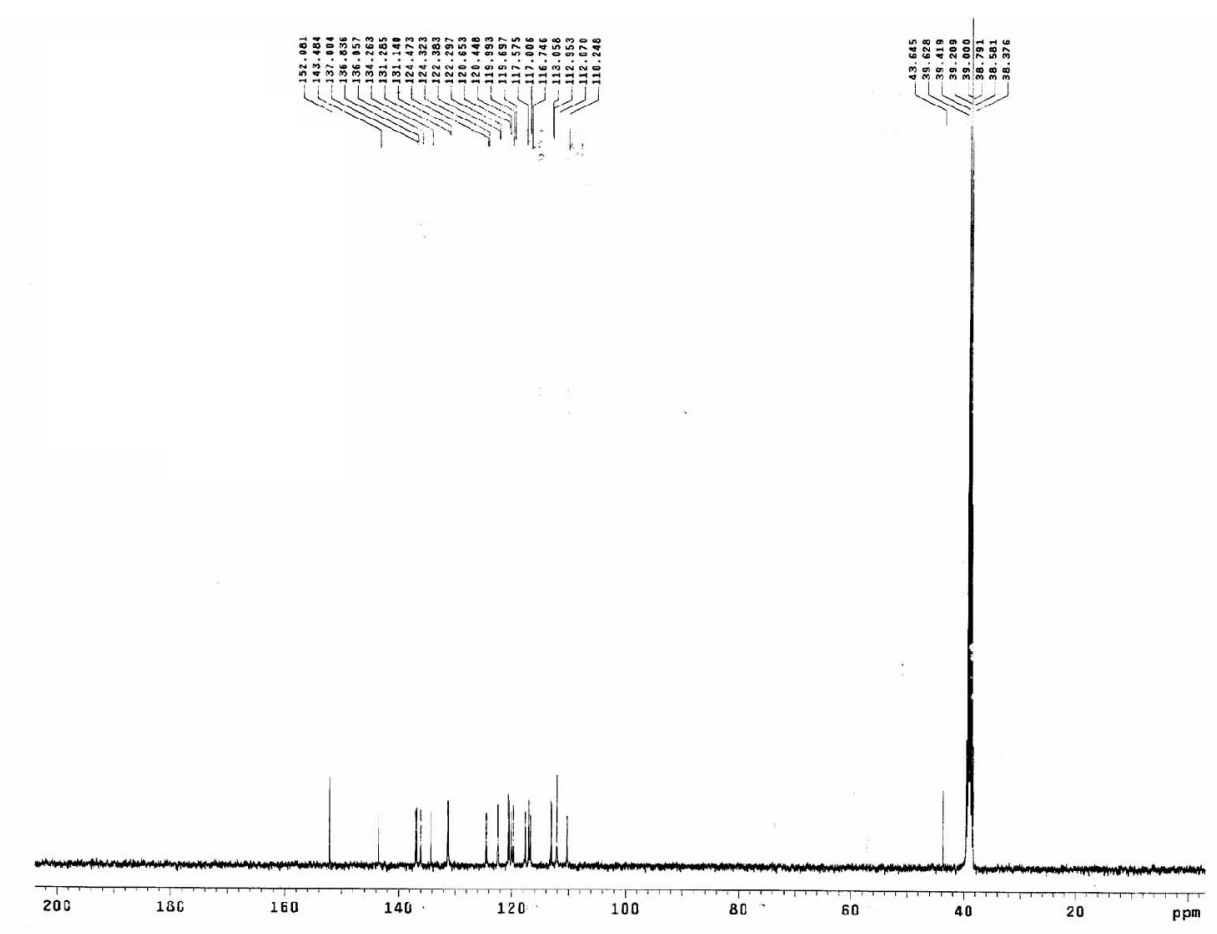

Figure S8. ${ }^{13} \mathrm{C}$ NMR spectrum of $\mathbf{3 a}$.

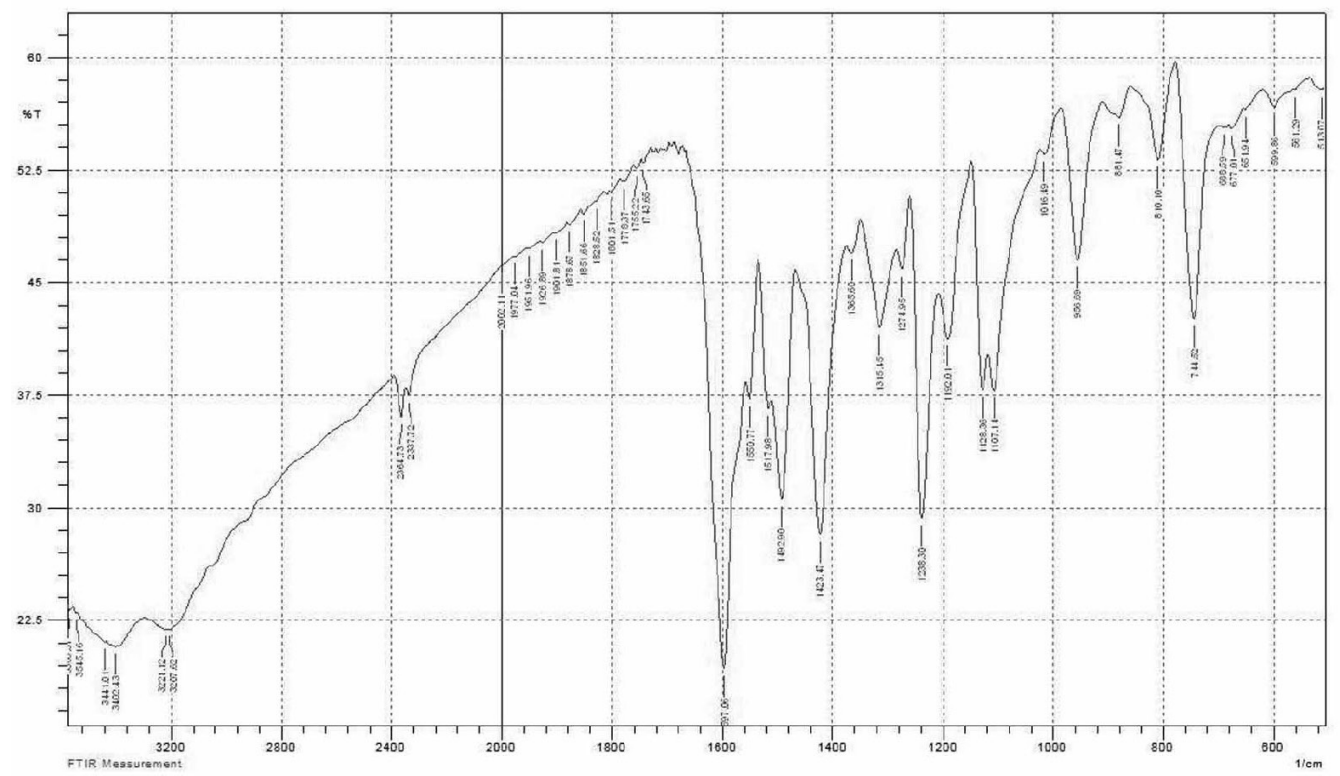

Figure S9. IR spectrum of $\mathbf{3 a}$. 
Trinucleus dimethine cyanine dye $\mathbf{3 b}$

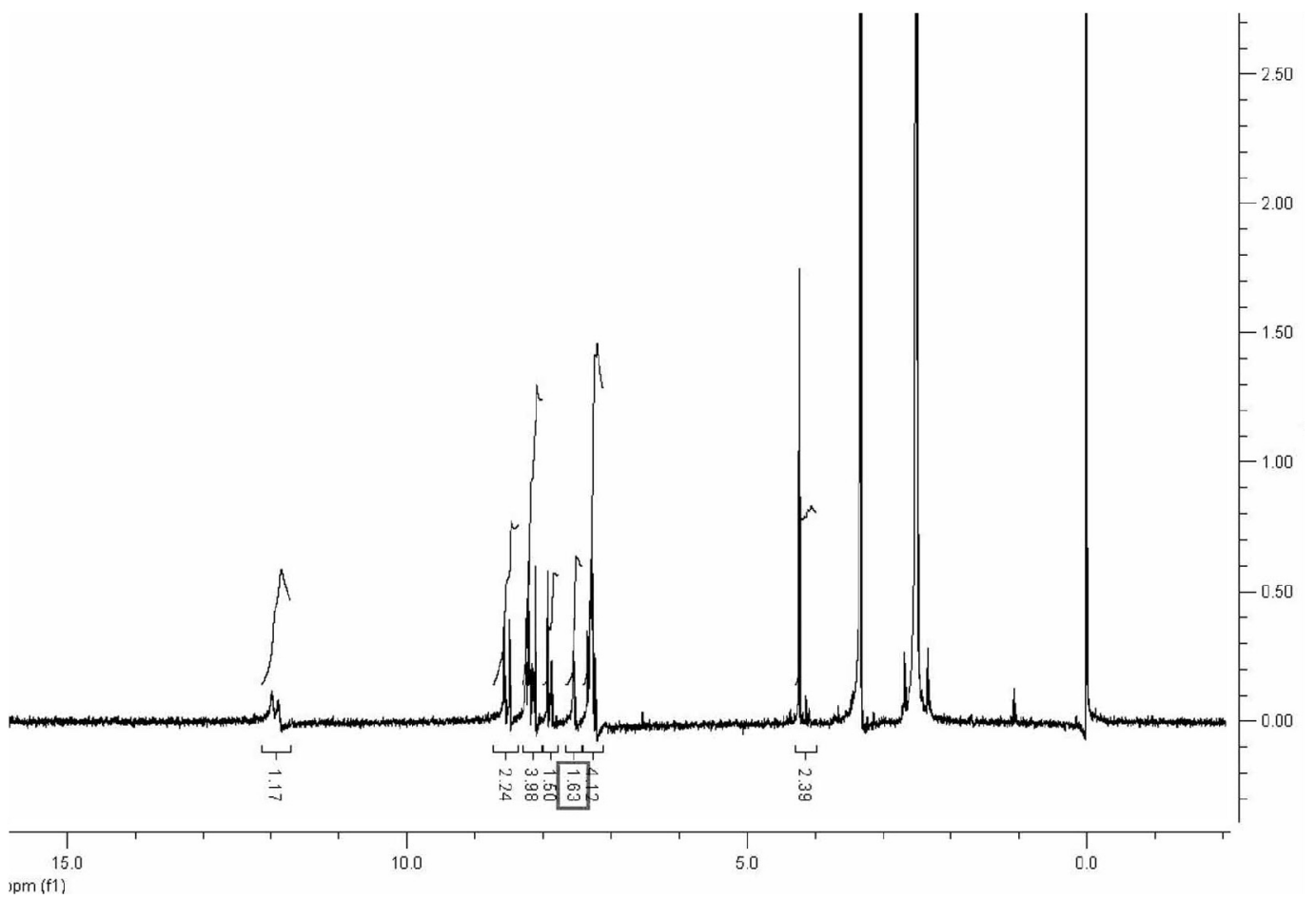

Figure S10. ${ }^{1} \mathrm{H}$ NMR spectrum of $\mathbf{3 b}$.
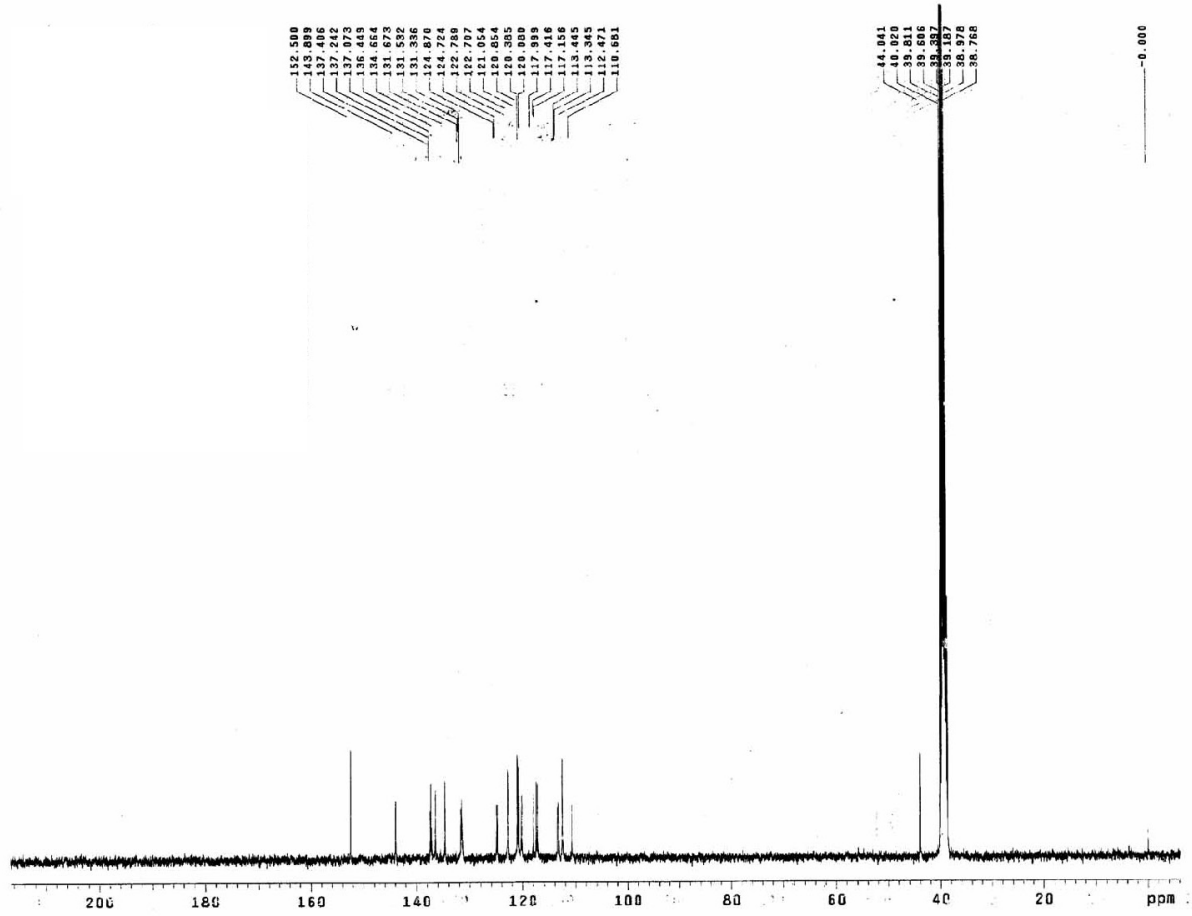

Figure S11. ${ }^{13} \mathrm{C}$ NMR spectrum of $\mathbf{3 b}$. 


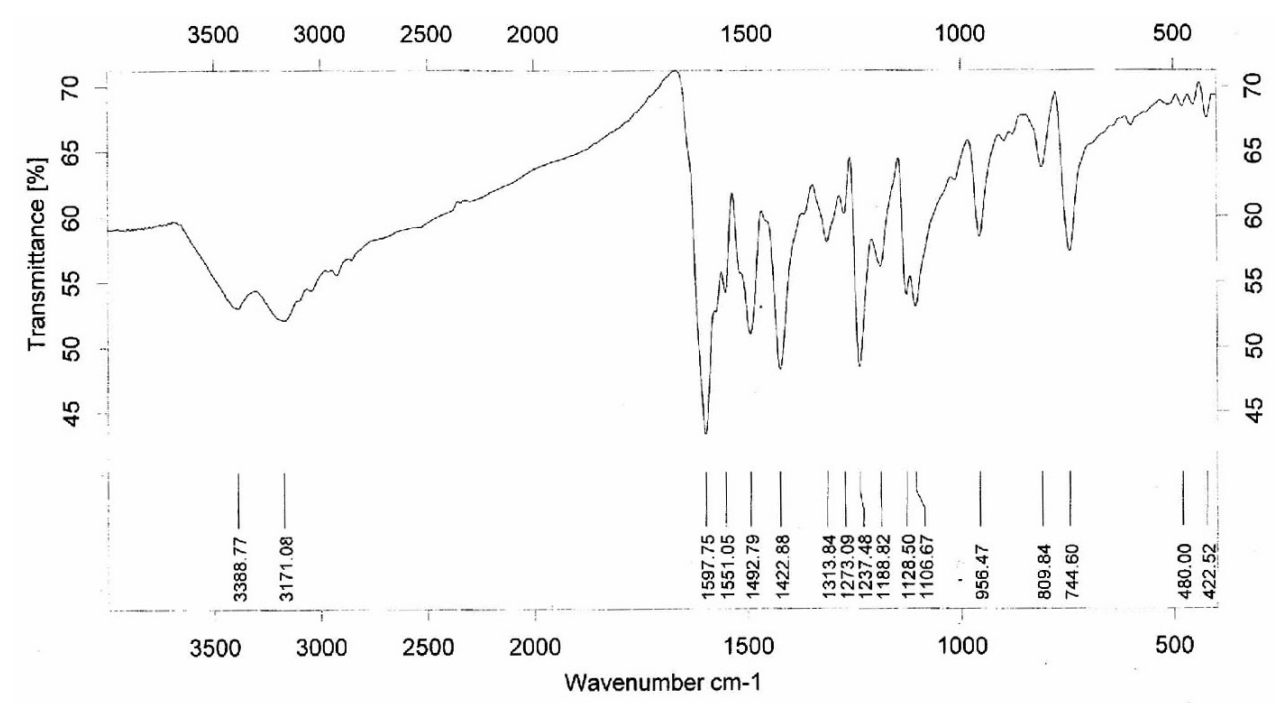

Figure S12. IR spectrum of $\mathbf{3 b}$.

Trinucleus dimethine cyanine dye $3 c$

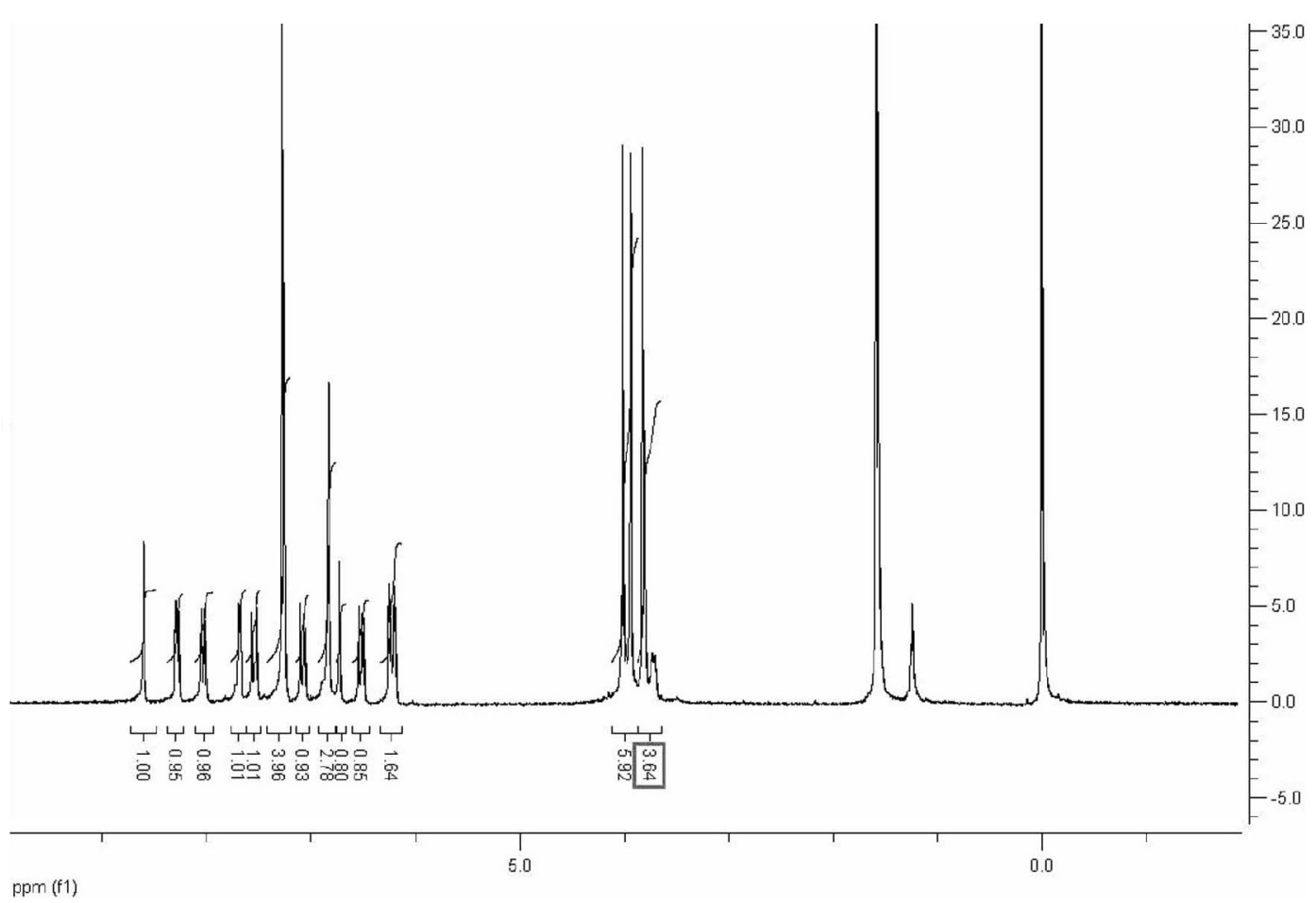

Figure S13. ${ }^{1} \mathrm{H}$ NMR spectrum of $\mathbf{3 c}$. 


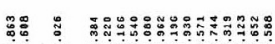

它安

Y

5⿻ำ

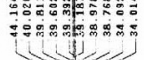

$\stackrel{a}{i}$
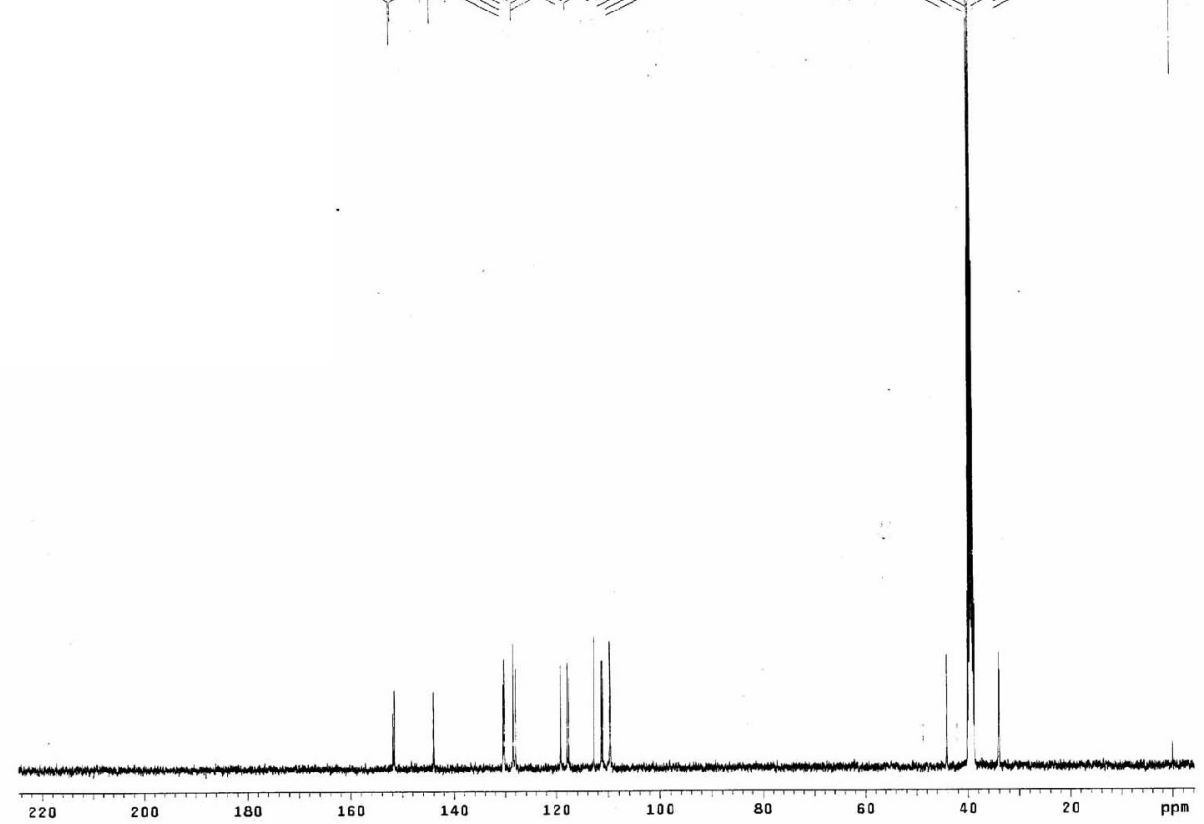

Figure S14. ${ }^{13} \mathrm{C}$ NMR spectrum of $\mathbf{3 c}$.

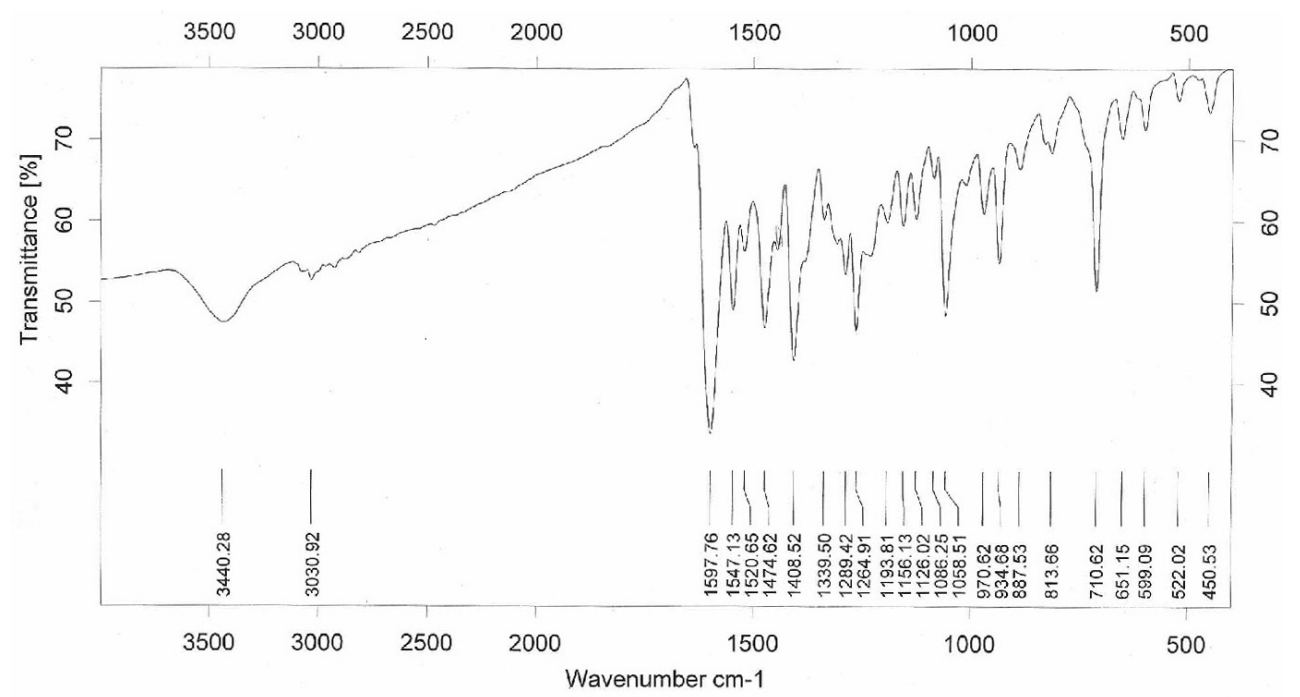

Figure S15. IR spectrum of 3c. 
Trinucleus dimethine cyanine dye $3 \mathrm{~d}$

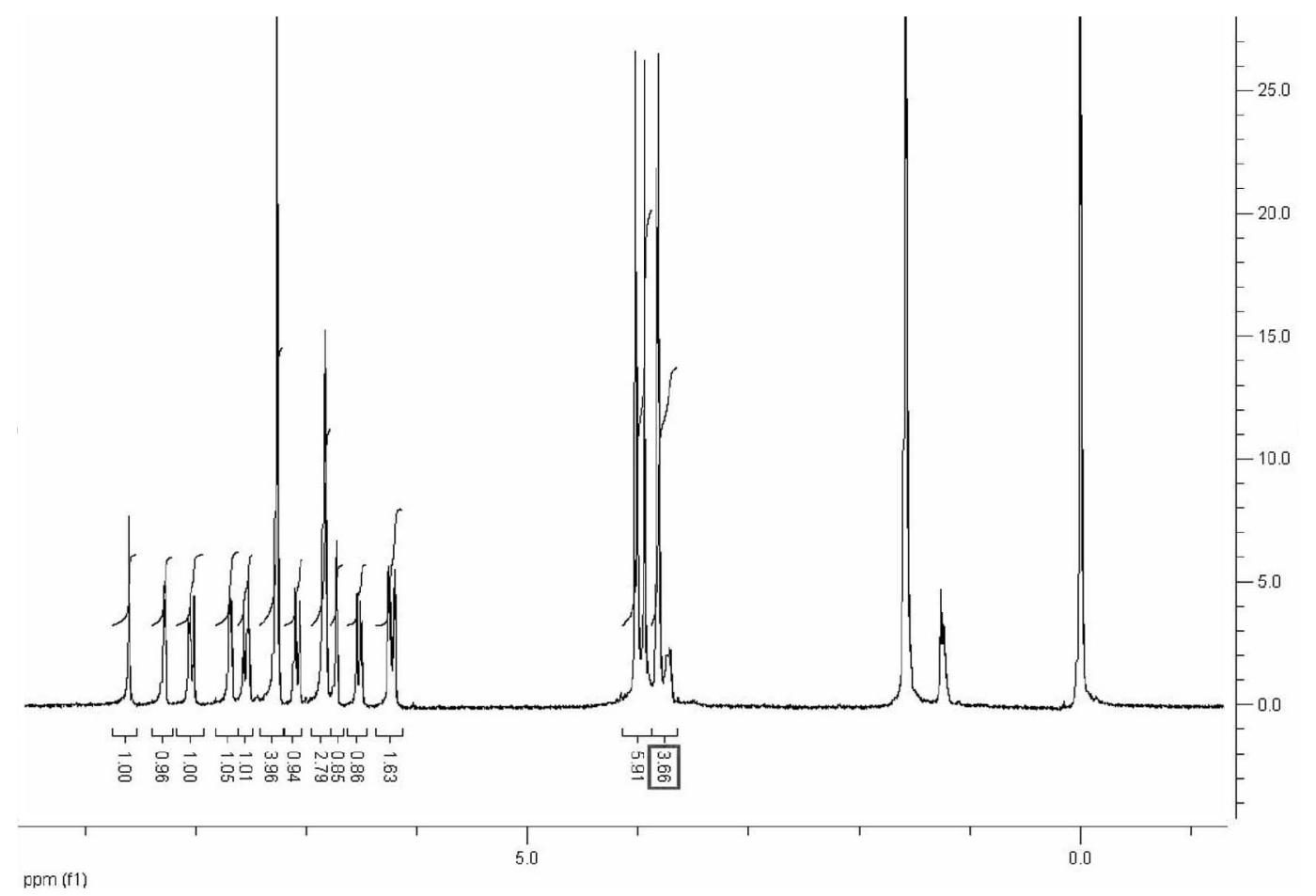

Figure S16. ${ }^{1} \mathrm{H}$ NMR spectrum of $\mathbf{3 d}$.

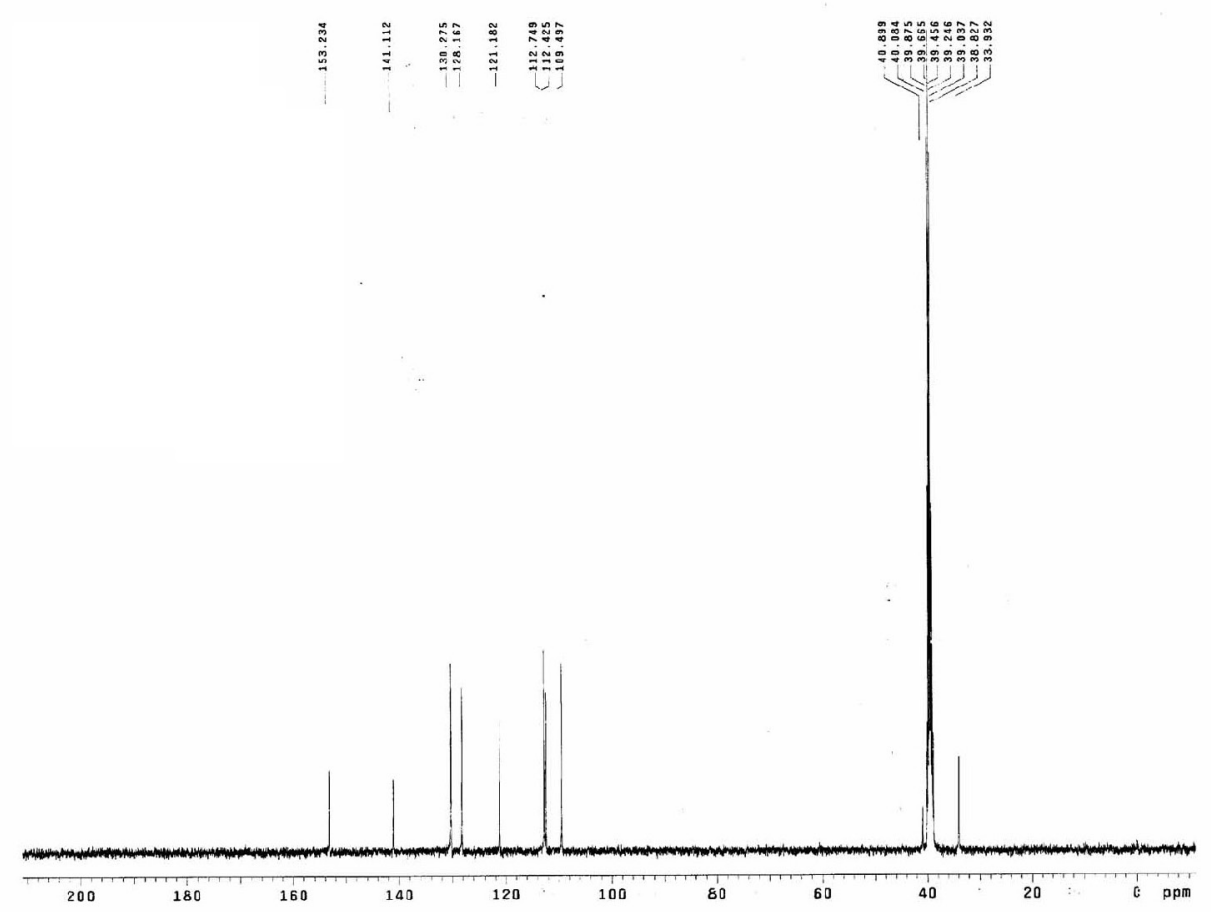

Figure S17. ${ }^{13} \mathrm{C}$ NMR spectrum of $\mathbf{3 d}$. 


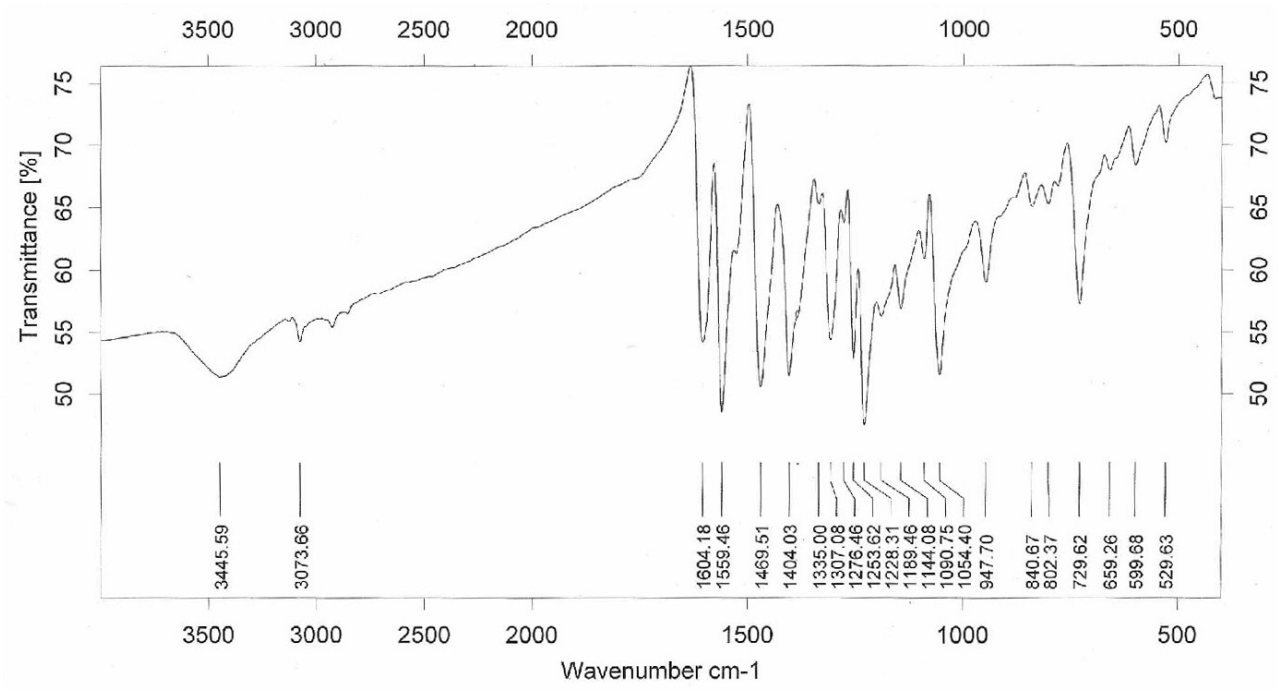

Figure S18. IR spectrum of $\mathbf{3 d}$.

\section{Trinucleus dimethine cyanine dye $\mathbf{3 e}$}

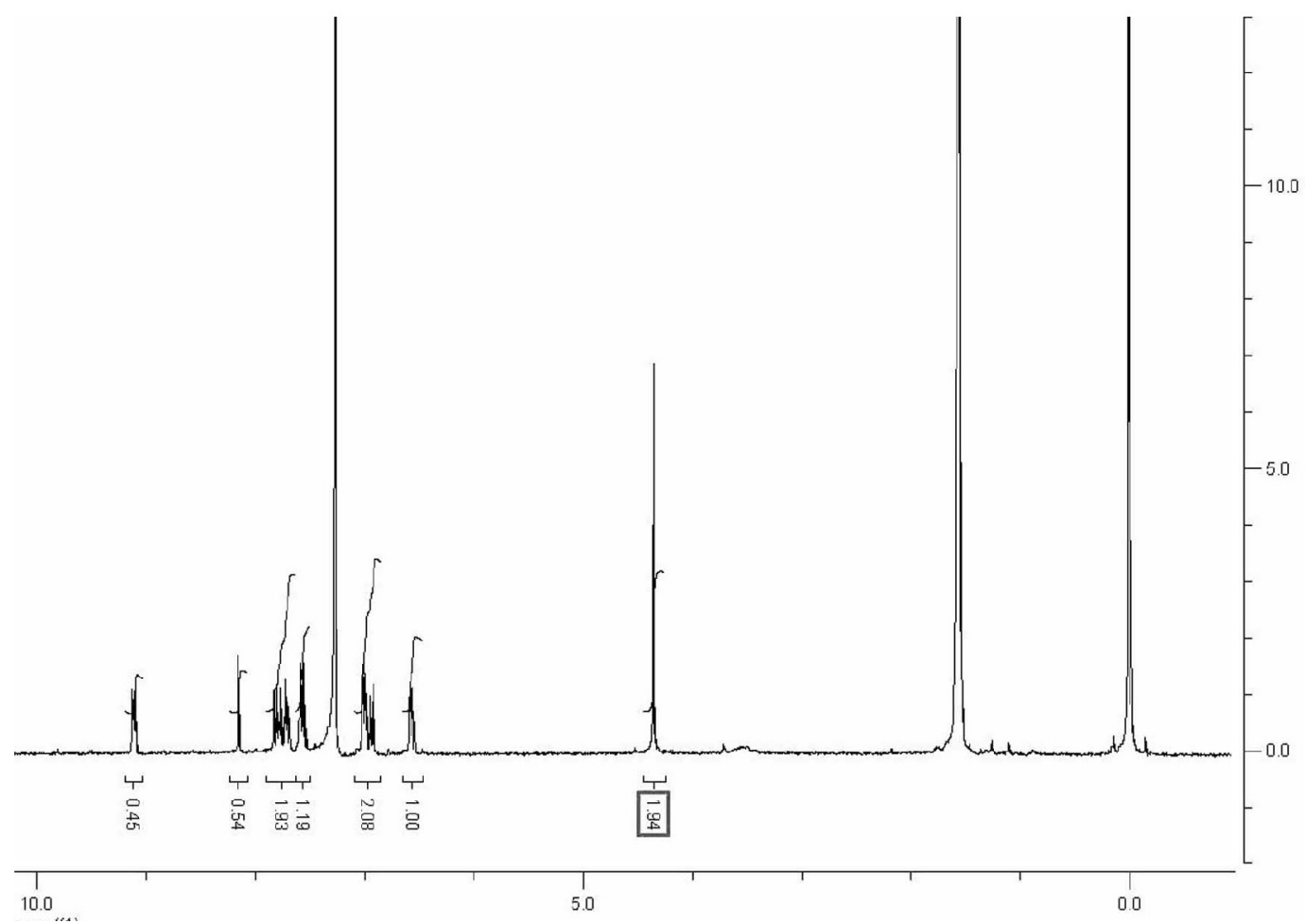

Figure S19. ${ }^{1} \mathrm{H}$ NMR spectrum of $\mathbf{3 e}$. 


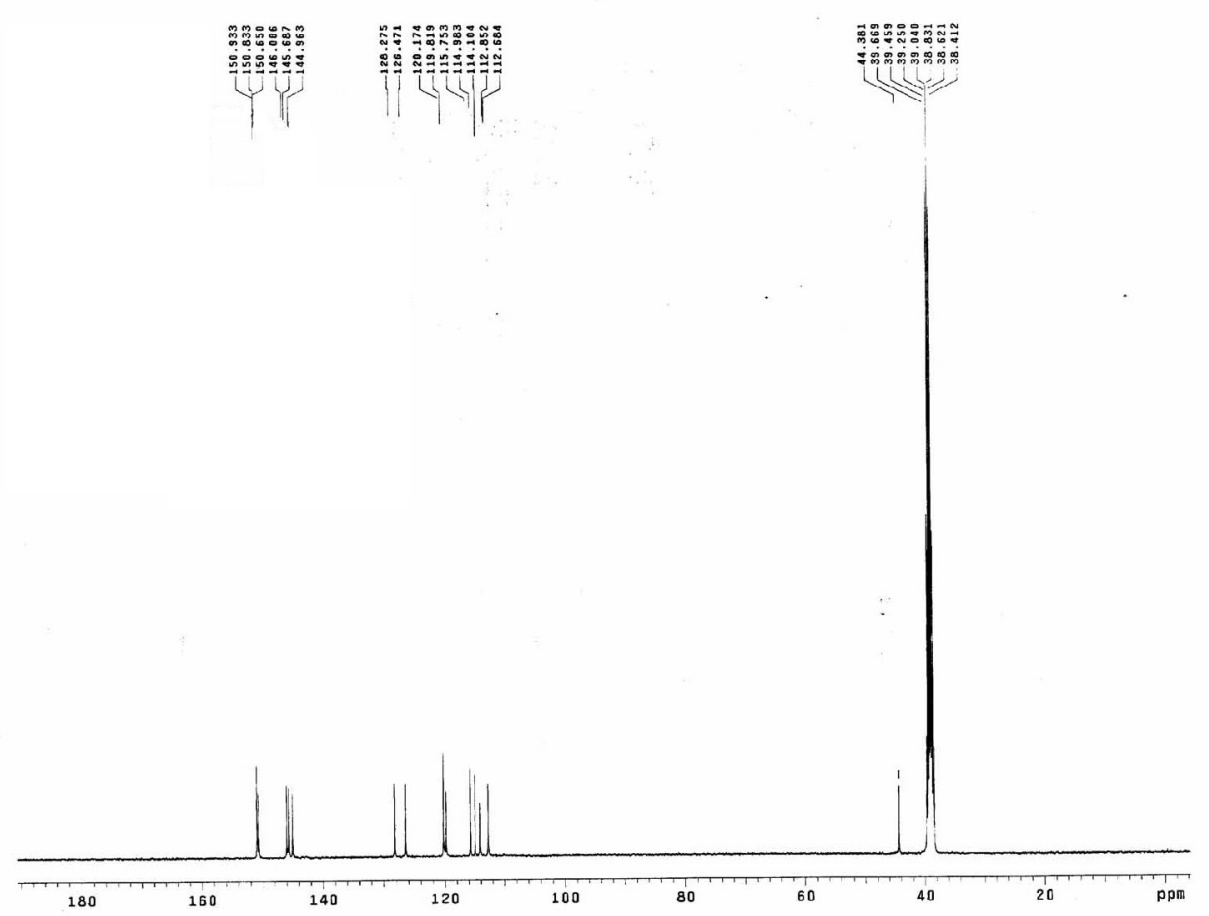

Figure S20. ${ }^{13} \mathrm{C}$ NMR spectrum of $\mathbf{3 e}$.

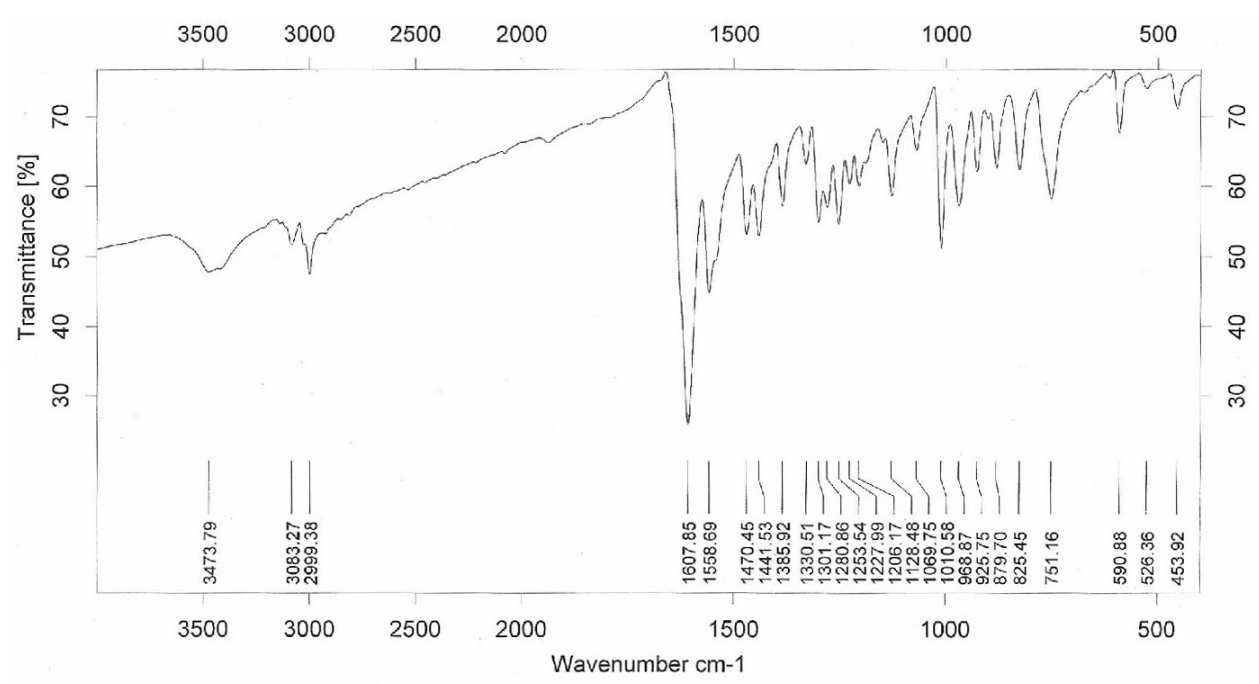

Figure S21. IR spectrum of 3e. 
Trinucleus dimethine cyanine dye $3 f$

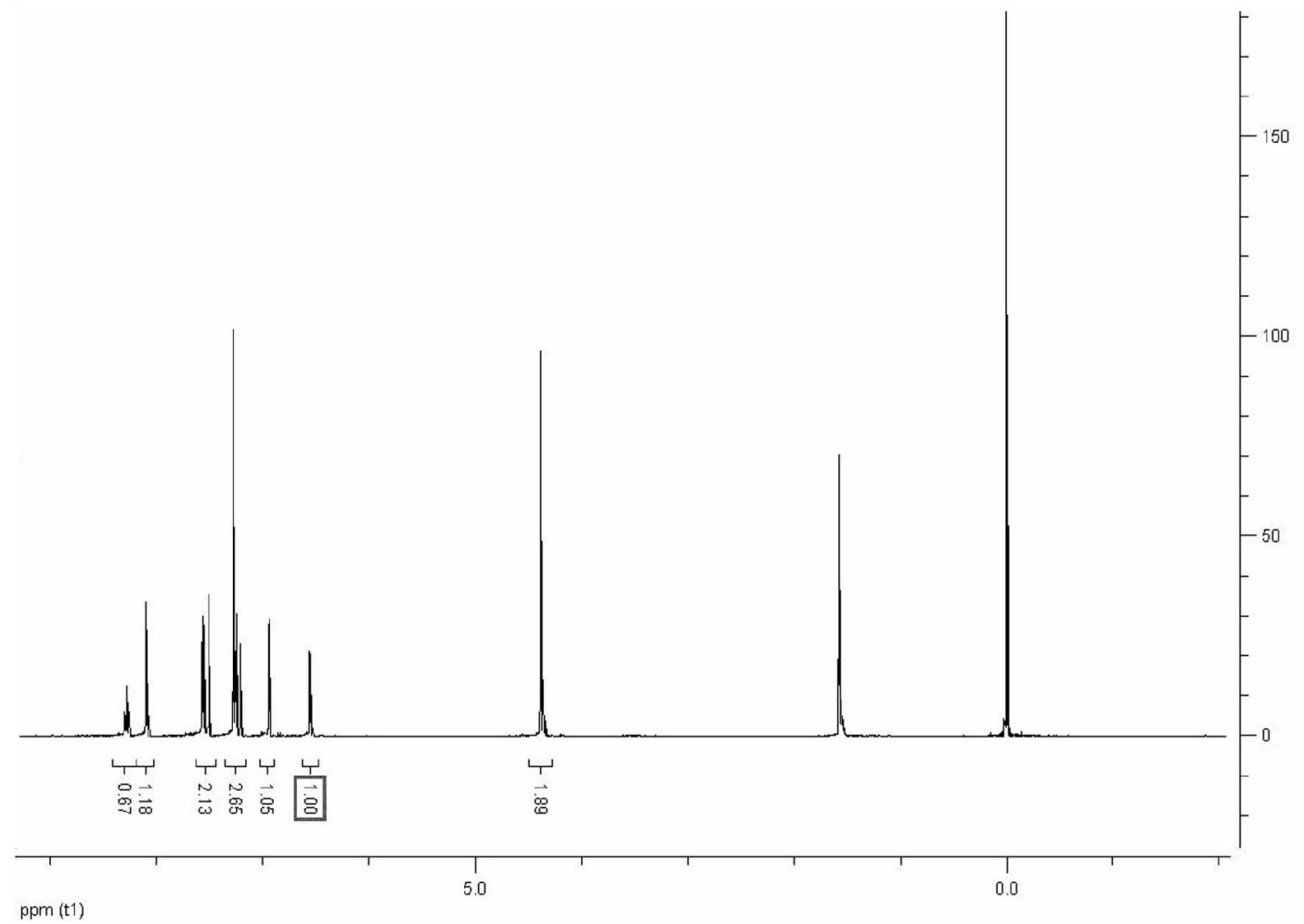

Figure S22. ${ }^{1} \mathrm{H}$ NMR spectrum of $\mathbf{3 f}$.

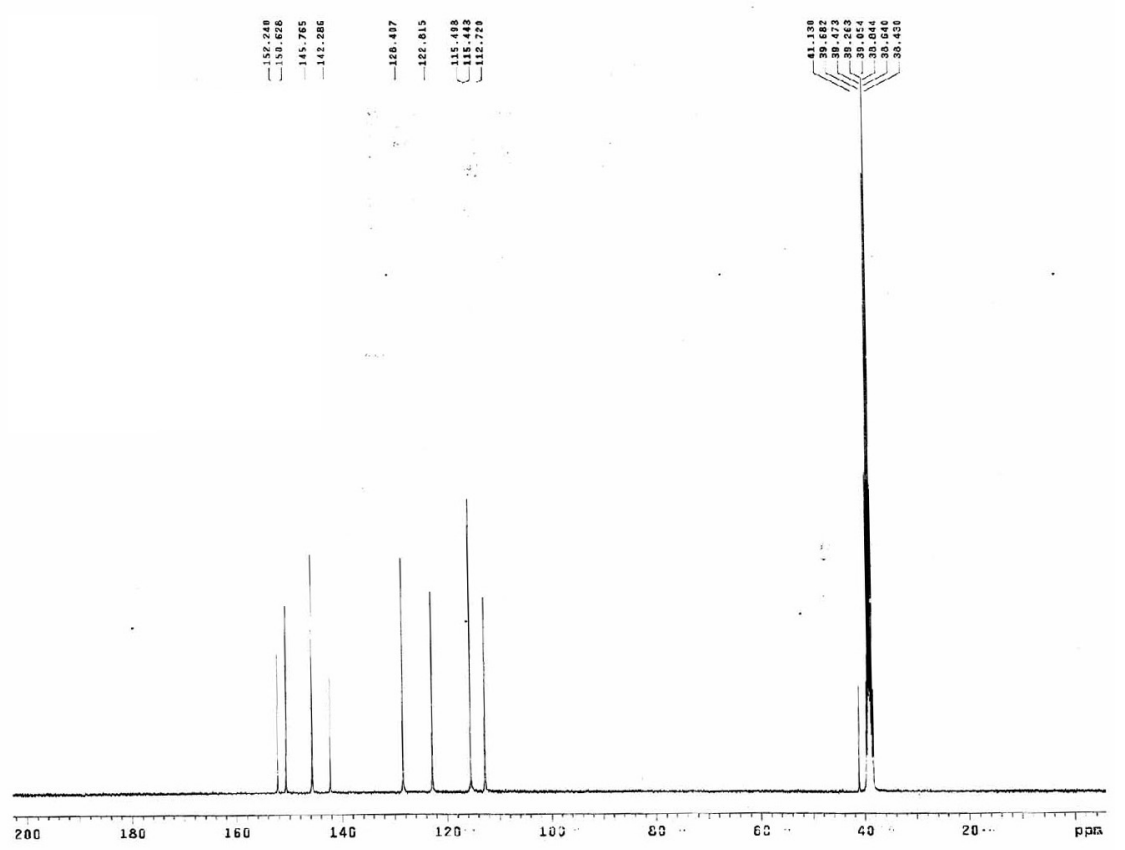

Figure S23. ${ }^{13} \mathrm{C}$ NMR spectrum of $\mathbf{3 f}$. 


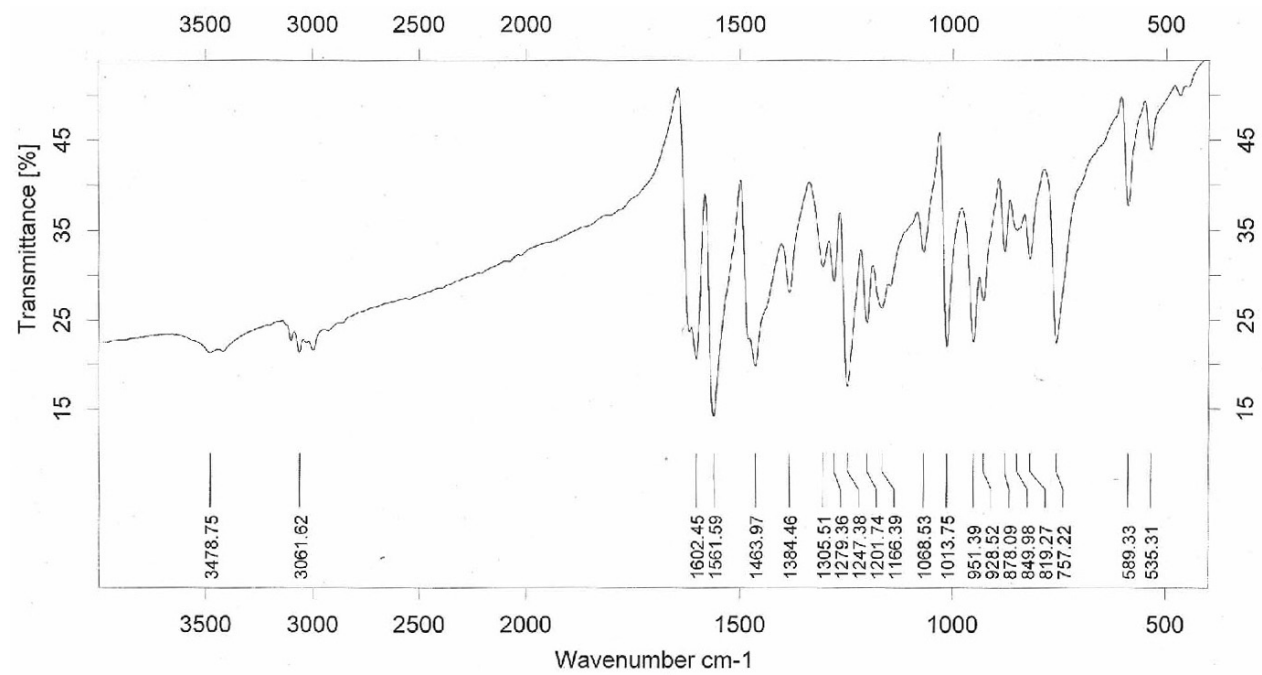

Figure S24. IR spectrum of $\mathbf{3 f}$. 